Int. J. Dev. Biol. 49: 595-614 (2005)

doi: $10.1387 /$ ijdb.052019lb

\title{
The making of gametes in higher plants
}

\author{
LEONOR C. BOAVIDA ${ }^{1}$, JÖRG D. BECKER ${ }^{1}$ and JOSÉ A. FEIJÓ*,1,2 \\ ${ }^{1}$ Centro de Biologia do Desenvolvimento, Instituto Gulbenkian de Ciência, Oeiras, Portugal and ${ }^{2}$ Universidade de Lisboa, Faculdade de \\ Ciências, Dept. Biologia Vegetal, Campo Grande, Lisboa, Portugal
}

\begin{abstract}
Higher plants have evolved to be one of the predominant life forms on this planet. A great deal of this evolutionary success relies in a very short gametophytic phase which underlies the sexual reproduction cycle. Sexual plant reproduction takes place in special organs of the flower. In most species the processes of gametogenesis, pollination, syngamy and embryogenesis are sequentially coordinated to give rise to a functional seed in a matter of few weeks. Any of these processes is so intricately complex and precisely regulated that it becomes no wonder that each involves more specific genes and cellular processes than any other function in the plant life cycle. While variability generation - the evolutionary output of the sexual cycle - is the same as in any other Kingdom, plants do it using a completely original set of mechanisms, many of which are not yet comprehended. In this paper, we cover the fundamental features of male and female gametogenesis. While the physiological and cellular bases of these processes have been continuously described since the early nineteen century, recent usage of Arabidopsis and other species as central models has brought about a great deal of specific information regarding their genetic regulation. Transcriptomics has recently enlarged the repertoire and pollen became the first gametophyte to have a fully described transcriptome in plants. We thus place special emphasis on the way this newly accumulated genetic and transcriptional information impacts our current understanding of the mechanisms of gametogenesis.
\end{abstract}

KEY WORDS: pollen, embryo sac, gametogenesis, microsporogenesis, macrosporogenesis

\section{The uniqueness of a life form}

One of the most remarkable features of life on earth is diversity, a great deal of which is based on the evolutionary output of sexual reproduction. Unlike animals, in which the primordial germ line develops early during embryogenesis, higher plants alternate the growth of the diploid sporophyte organism with a highly reduced growth form on the plant life cycle, the haploid gametophyte. This is a well-suited strategy for selection because plants spend most of their life on the vegetative phase. The gametophytic stage also presents an opportunity for selection at the haploid level (Ottaviano et al., 1990).

Plant cells don't move and positional information instead of lineage is the primary determinant of cell fate in plants. Meiosis triggers the separation between sporophytic and gametophytic generations involving various genes (Caryl et al., 2003). This spatial pleiotropy of the sexual organs has prompted evolution for the appearance of safety mechanisms to prevent the fusion of incompatible genomes while supporting genetic variability. In higher animals genetic mechanisms for sex determination establish striking developmental differences between males and fe- males. In contrast, most higher plant species develop both male and female structures within the same flower, allowing selffertilization. Out-crossing is ensured by self-incompatibility mechanisms, which evolved under precise genetic control controlling self-recognition and cell-to-cell interaction (Thomas and FranklinTong, 2004).

The short period that plants spend on their reproductive cycle includes some of the most intriguing and challenging questions in biology, many yet without a mechanistic answer. With the publication of the complete genomic sequence of the flowering plant Arabidopsis thaliana (The Arabidopsis Genome Initiative, 2000), new foundations for functional and comparative genomics emerged to reveal basic genetic differences between plants and other eukaryotes. Although the logic underlying many of the developmental processes as pattern formation and cell-cell communication are comparable between plants and animals, the master regulators are unrelated or represent novel protein rearrangements which serve identical functions (Meyerowitz, 2002), making many genes unique to plants. It is therefore of no surprise that we find this prediction mirrored on the various stages of sexual plant reproduction.

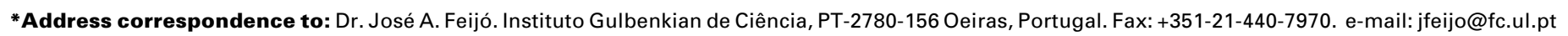




\section{Gametogenesis in the major group of vascular plants: the angiosperms}

The phylum Anthophyta, i.e. the Angiosperms (from the Latin word angi, "enclosed" and Greek word sperma, "seed") or flowering plants, is the dominant group of land plants today. They arose about 140 million years ago during the late Jurassic and experienced rapid diversification during the Cretaceous. There are more than 250000 species, grouped into 12500 genera and about 300 families and in terms of ecological and nutritional importance they surpass all other groups. Numerous traits contributed to this rise to dominance, including the ability to reach reproductive maturity rapidly and adaptation to animal pollination and seed dispersal (Darwin, 1862). Flowers, the reproductive organs of angiosperms, are more varied than the equivalent structures of any other group of organisms (Barrett, 2002).

The life cycle of higher plants includes seed germination, vegetative growth, flowering, fertilization, development of embryo and seed maturation. Induction of flowering is triggered by environmental cues such as light, temperature and nutrient access, in combination with endogenous signals (e.g. the plant hormone gibberellin and circadian'oscillators), for which many flowering time genes are described (Mouradov etal., 2002). The integration of signals directs the activation of meristem identity genes, which specify floral identity and the shoot apical meristem is transformed into an inflorescence. Finally, the floral organ identity genes are activated in different regions of the flower, producing four organ types, sepals, petals, the male stamens, collectively named the androecium and the female carpels, making up the gynoecium, or the pistil, located in the innermost whorl (Smyth et al., 1990). Such are the organs were male and female gametogenesis take place respectively.

\section{The male gametophyte - pollen}

The development of the male gametophyte involves a series of events culminating in the production and release of mature pollen grains from anthers (McCormick, 1993, 2004). Mature pollen grains may be considered as a "cell within a cell", with very specialized functions. Enclosed by a very special cell wall, the vegetative cell harbors an individual cytoplasm with a particular gene expression pattern. Its final fate is to transport the two sperm cells through the female tissues and release them in the vicinity of the egg and central cells (see review by Boavida et al., 2005).
It all begins in stamens, the male reproductive organs, which consist of an anther, where pollen development takes place and a stalk-like filament which provides support, nutrient transport and positions anthers to facilitate pollen dispersal (Scott et al., 1991a; Irish, 1999). Stamens are derived from periclinal divisions of the L2 layer of the shoot apical meristem (Jenik and Irish, 2000).

Pollen development takes place within the anther locus, or pollen sac (Fig. 1D), involving perhaps more genes than any other single process in plant development and depends on interactions between sporophytic and gametophytic cells (Scott et al., 2004). Both are essential for male fertility as revealed by numerous genetic screens (van der Meer et al., 1992; Chen and McCormick, 1996; Aarts etal., 1997; Hulskamp etal., 1997; Taylor etal., 1998; Ariizumi et al., 2003).

Anther differentiation will lead to the production of several specialized cells and tissues involved in reproductive or nonreproductive functions (e.g. support and dehiscence) (Koltunow et al., 1990). The male gametogenesis starts from L2 cells of the shoot apical meristem, that divide to form a primary parietal cell (PPC) and the primary sporogeneous cells (PSC). The PPC later form several concentric layers on the anther wall, which differentiate into the endothecium, middle and the very special inner layers, known as the tapetum (Fig. 1A). PSC give rise to the microsporocytes. Coordination of the process is under tight genetic control (Goldberg et al., 1993).

The development of viable pollen grains is dependent on the presence of the tapetum, which has roles in the nourishment of microspores, formation of exine and deposition of tryphine on the pollen wall (Koltunow et al., 1990; Mariani et al., 1990; Goldberg et al., 1993). A summary of major developmental events on male gametogenesis with the correspondent anther differentiation stages is represented on Figure 1.

When microspores initiate meiosis, coenocytic masses are established by enlarged plasmodesmata, the cytomictic channels (Fig. 1B), which create a cytoplasmic continuum between groups of cells. This way, there is an effective synchronization during microsporogenesis, by allowing exchange of molecules and ions (Heslop-Harrison, 1966; Mascarenhas, 1975). Microsporocytes are encased in an impermeable $\beta-1,3-$ glucan wall (callose), isolating the meiocytes from the sporophyte cells (Fig. 1E). The callosic wall was proposed to function as a sieve for large molecules whose influence could impair the commitment to an haploid genomic expression (Mackenzie etal., 1967; Mascarenhas, 1975). However, the apparent ability of large molecules to trans-

Fig. 1 (opposite). A generalized overview of microsporogenesis and pollen development. Schematic representations were adapted from Goldberg et al. (1993) and McCormick (1993). C, connective; CCC, circular cell cluster; E, epidermis; En, endothecium; PG, pollen grain; PS, pollen sac; St stomium; $T$, tapetum; Td tetrads; $V$, vascular bundle. See text for description of developmental events. Individual steps are illustrated with transmitted electron microscopy (TEM) micrographs or TEM-prepared semi-thin sections seen with light microscopy of microsporogenesis of the orchid Ophrys lutea (Feijó, 1995). (A) Individualization of a group of sporogeneous cells by a callose envelope. These cells will divide to final size and enter male meiosis. (B) Meiocytes are connected by large channels, named cytomictic channels (CC), through which a general streaming, including organelles like plastids (PI) is believed to contribute to the synchronization of meiosis within the whole population. (C) Telophase II, with twin mitotic spindles (f1 and f2) within a callose enclosed tetrad. (D) Mid section of an immature flower showing the relative position of the male gametophyte forming organs, the pollen sacs (Pol1 and 2) and the female gametophyte forming organs, the ovules in the ovary (OV). (E) Up until the end of meiosis, each microspore is enclosed on a callose wall and groups of microspores are individualized from surrounding tissues by thick callose walls (Cal), here stained with decolorized aniline blue. (F) Formation of individualized microspores within a meiotic tetrad $(1,2,3,4)$. Note the synchronization of one mass of meiocytes in telophase II, while the upper mass is already synchronized in microspore individualization. (G) Polarization and vacuolization of the young microspore. The nucleus is strongly pulled out to one end of the cell, while the plastids are on the opposite end. Small vacuoles are formed to account for the enlargement of the cell and later will coalesce in a single big vacuole. (H) Synchronized pollen mitosis I. The mass of microspores on the right is still on anaphase and on the left cytokinesis already occurred (arrow), dividing a small generative cell and a big vegetative one. (I-K) Process of pinching-off the generative cell. 


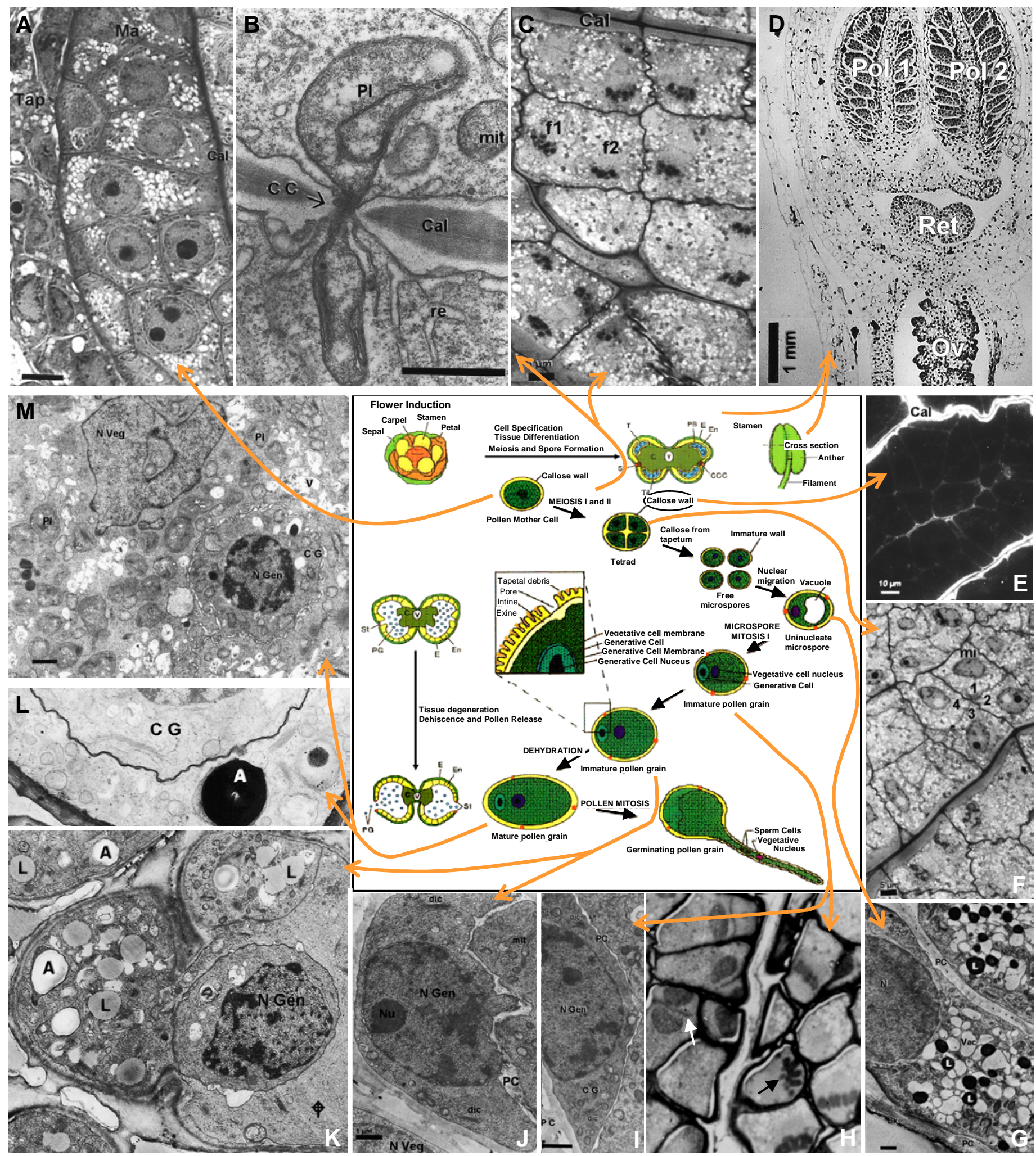

Initially appressed against the outer cell wall (I) soon the callose wall start to degrade and deform (J) and finally breaks allowing the pinching-off and migration of the generative cell to a central position on the pollen grain (K). In this last step the cytosol surrounding the generative is impressively active, with numerous dictyosomes and a huge number of secretory vesicles. The generative cell (CG) is individualised within the vegetative cell (CV) cytoplasm by a double membrane, a thin polysaccharide extracellular matrix (L) here shown by the Thiéry/PatAg test (see the intense staining of the starch on the amyloplastid A). (M) Final dehydrated bicellular pollen grain with a typical pleiomorphic vegetative cell nucleus and the round generative cell on a central position. 
verse this barrier raised some doubts about its actual function (Scott et al., 2004).

Two meiotic divisions transform then each microsporocyte (or pollen mother cell) into a tetrad of haploid microspores, each with its own callose envelop and all encased in the callose wall of the tetrad (Fig. 1 E,F). At this stage the cytomictic channels disappear, establishing an individual cytoplasm in each microspore cytoplasm. During meiosis the levels of rRNA and mRNA decrease dramatically and plastids and mitochondria populations undergo a cycle of dedifferentiation and replication. These changes at the cytoplasmic level are believed to reset the sporophytic program and launch the gametophytic functional program (Bird et al., 1983). Pollen wall deposition also initiates and a prim(exine) layer develops around each microspore which will become visible at tetrad stage of pollen maturation (Heslop-Harrison, 1963, 1971)(Fig. 2B).

STUD (STD) and TETRASPORE (TES) genes were shown to be essential for cytokinesis. The stud/tes mutants form large tetranucleate microspores with a common cytoplasm, lacking intersporal walls. However, up to four pairs of sperm cells are observed in stud and tes pollen grains (Hulskamp etal., 1997; Spielman et al., 1997; Yang et al., 2003), suggesting that meiotic cytokinesis and cytoplasmic isolation are not prerequisites to establish cytoplasmic polarity in each microspore.

In most species, dissolution of the callose wall by callases releases the haploid microspores from the tetrad (McCormick, 1993). The timing of callase secretion appears to be critical for normal pollen development (Frankel et al., 1969; Worrall et al., 1992). The Arabidopsis gene, glucan synthase-like5 (AtGs/5), encoding a plasma membrane-localized protein homologous to yeast $\beta-1,3$ glucan synthase (callose synthase), has been shown to partially complement the yeast mutant. The gene is developmentally expressed at high levels in flowers and may represent the callose synthase required for deposition of callose in pollen (Ostergaard et al., 2002). In tobacco, the downregulation of TAG1 gene, which encodes a $\beta$-1,3-glucanase expressed in the tapetum, was shown not to affect tetrad dissolution and pollen development (Bucciaglia et al., 2003). A candidate gene required for tetrad dissolution is QUARTET (QRT). In quartet (qrt) mutants pollen grains are released as tetrads and callose patches are observed between the fused walls. However, the failure on microspore separation has been traced to the persistence of pectin components on the pollen walls (Preuss et al., 1994; Rhee and Somerville, 1998). QUARTET 3 was recently cloned, showing homology to an endo-polygalacturonase and expression on the tapetum; moreover, when expressed in yeast, it shows polygalacturonase activity (Rhee et al., 2003), confirming a role for pectins on tetrad integrity.

After release, haploid microspores undergo cytoplasmic reorganization, small vacuoles coalesce into a single vacuole, which polarizes most of the cytoplasm to one side of the cell periphery (Fig. 1G) and the nucleus on the other side, a process mediated by the cytoskeleton (Brown and Lemmon, 1991; Zonia et al., 1999). This polarization leads to an asymmetric division called pollen mitosis I (PMI) (Fig. 1 G-J), essential for the differentiation of a big vegetative cell (VC) and a small generative cell (GC), which later will generate the sperm cells (Fig. $1 \mathrm{H}-\mathrm{J}$ ). This division can be viewed as determinative since the two daughter cells will have different cell fates (Horvitz and Herskowitz, 1992). Models have been proposed to explain the different cell fates by polarised distribution of gametophytic regulatory factors, resulting in the repression of the vegetative cell specific genes on the generative cell as a result of asymmetric division (Eady et al., 1995). These models led to the conventional assumption that the generative cell or sperm cell nuclei are transcriptionally repressed (McCormick, 1993).
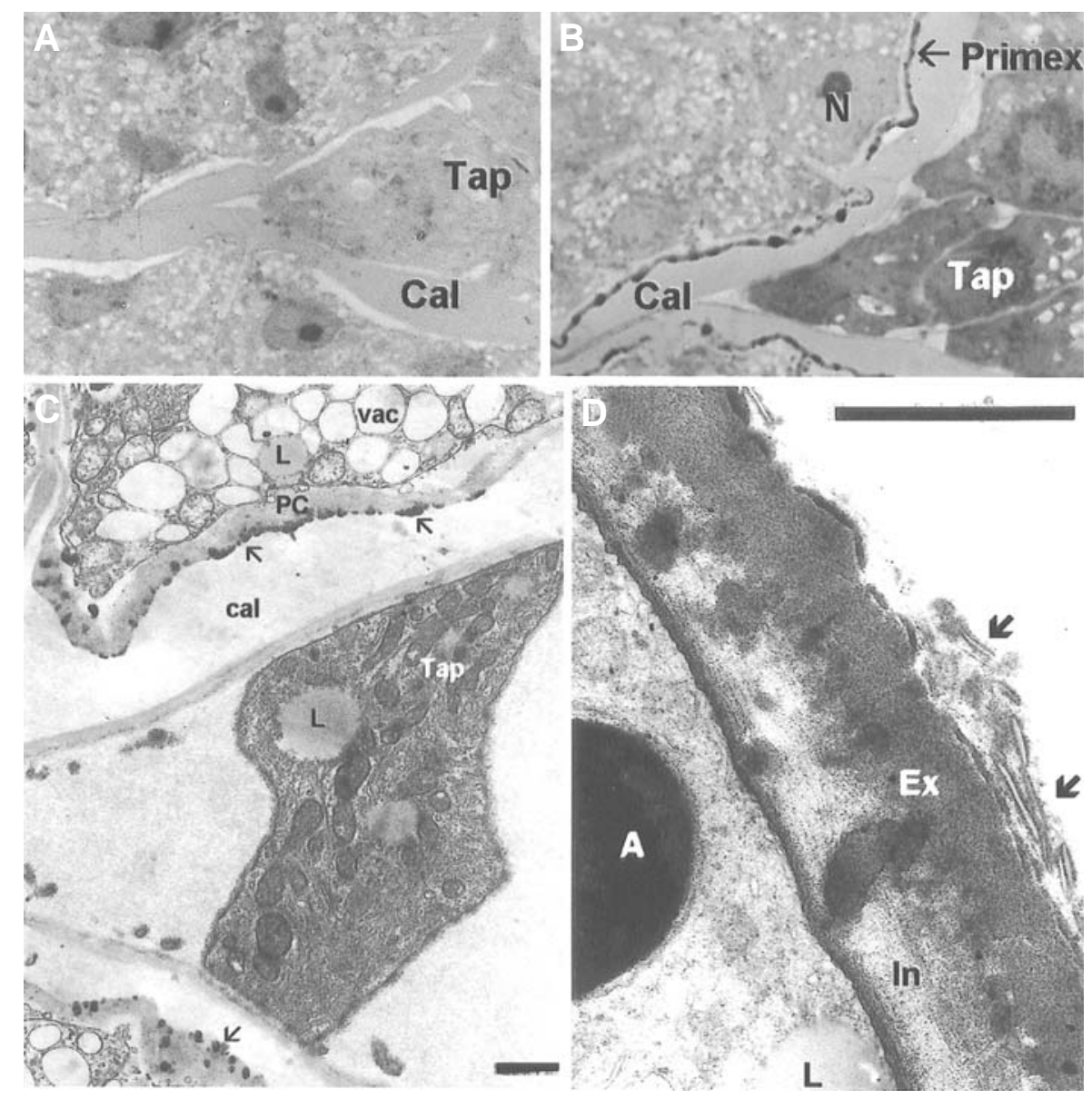

Fig. 2. Formation of the special pollen wall, the exine on O.lutea. (A) Young microspore stage, with active ameboid tapetum cells (Tap) and a thick isolating callose layer (Cal). (B) Late microspore stage, with degenerating tapetum cells and beginning of deposition of the first layer of sporopollenin, named primexin (Primex). (C) Same stage observed with detail using TEM. The first deposition is basically organized in small spots, originating from tapetal secretion. Callose is still very thick. (D) Final structure of the pollen wall, with the pectocellulosic Intine (In), the sporopollenin Exine (Ex) and later deposited membrane like structure which may contain recognition proteins (arrows). 
Genetics screens in Arabidopsis based on alterations to the typical tricellular pollen morphology yielded mutants affected on cell division. Sidecar ( $s c p$ ) was the first gametophytic mutant shown to affect microspore division symmetry: the microspore goes through a premature symmetrical division, but one of the daughter cells divides asymmetrically producing a normal VC with two sperm cells, supporting the hypothesis that an asymmetric localization of a polarity factor exists before PMI (Chen and McCormick, 1996). In two-in-one pollen (tio) mutant the mature pollen grains contain two nuclei, due to a failure of cytokinesis at pollen mitosis I (Twell and Howden, 1998; Twell et al., 1998). However, tio microspores undergo maturation and are able to activate a vegetative cell fate marker, indicating that $\mathrm{VC}$ fate is the default program in absence of PMI. The geminipollen 1 (gem1) mutant is affected in microspore polarity, asymmetric cell division and cell fate. The gene was shown to encode a microtubule associated protein required for the correct localization of the fragmoplast during cytokinesis (Park et al., 1998; Twell et al., 2002). After PMI the GC cytoplasm becomes isolated from the VC by a thin callose wall that fuses with the inner pollen wall, named intine (Fig. $1 \mathrm{I}, \mathrm{J})$. This wall is then degraded by the mobilization of $\beta-1,3-g l u c a n a s e s$, allowing the $\mathrm{GC}$ to detach from the intine wall (Fig. $1 \mathrm{~J}, \mathrm{~K}$ ). The round GC is then "engulfed" by the VC cytoplasm acquiring a central position on the pollen grain (Fig. 1K). Later the GC undergoes a morphogenetic process, acquiring an elongated or spindle-like shape, which is stabilized by the microtubule arrays aligned along the GC (Fig. 1 L-M). While not possessing a true cell wall, the mature $\mathrm{GC}$ does possess an external extracellular matrix of polysaccharide nature (Fig. 1L). On the gametophytic mutant limpetpollen (lip) GC migration is blocked after PMI and generative or sperm cells remain at the periphery of the pollen wall. Since in limpet pollen, the transient wall material that separates the GC from the VC persists, LIP is believed to either regulate the delivery of $\beta-1,3$-glucanases or to encode general products required for the GC migration (Howden et al., 1998).

In many species the generative cell divides before pollen release into two identical sperm cells (tricellular pollen), while in others this division only occurs after pollen germination (bicellular pollen). At the end of this division (PMII) the vegetative nucleus and the two sperm cells will assume a specific structural arrangement, the male germ unit (MGU). Recently, the mud (male germ unit displaced) and gum (germ unit malformed) male-specific gametophytic mutants were shown to affect the integrity and/or the positioning of the MGU in the mature pollen grain. These mutants show reduced transmission through the male gametophyte (Lalanne and Twell, 2002).

The final steps of pollen maturation are usually coincident with floral anthesis and anther dehiscence, ending with the release of mature dehydrated pollen grains. Anther dehiscence is coordinated with pollen differentiation and involves three major tissue types, the stomium, the endothecium and the circular cell cluster. Several mutants related to jasmonic acid biosynthesis were demonstrated to be affected in anther dehiscence and cause male sterility (Zhao and Ma, 2000; Ishiguro etal., 2001; Park etal., 2002; Hatakeyama et al., 2003; Rieu et al., 2003). A male sterile mutant in Arabidopsis affecting the AtMYB26 transcription factor shows defects in anther dehiscence because the stamens lack cell wall fortifications in the endothecial cells, required for dehiscence (Steiner-Lange et al., 2003). Pollen is, however, viable and can fertilize when released mechanically from the anthers.

Mature pollen grains of angiosperms are released dehydrated (Fig. $1 \mathrm{M}$ ), with a water content of $15-30 \%$, which is associated with an almost inactive metabolism (Heslop-Harrison, 1979; Hoekstra and Bruinsma, 1980). Recently, the ADL1C gene, a member of the a dynamin-like protein family, was shown to be involved on the plasma membrane and intine morphology of post meiotic male gametophytes, with possible involvement on the formation and maintenance of the pollen surface and viability during desiccation (Kang et al., 2003).

\section{The pollen wall}

Spores and pollen of higher plants have enormous value in taxonomic studies, due to the species-specific wall structure and surface pattern. The consistency of the pattern within species suggests a high degree of genetic regulation for which there is no obvious explanation. This issue raised an intensive debate whether the establishment of the pollen wall pattern is a consequence of a self-assembly process due to the physical and chemical behavior of the components and their interactions, or if it depends only on a complex cooperation of cellular components (Sheldon and Dickinson, 1983; Fitzgerald and Knox, 1995; Southworth and Jernstedt, 1995; Paxson-Sowders et al., 1997; Hemsley et al., 2003).

Pollen wall formation begins soon after meiosis is complete (Fig. 2 A,B) and it continues during tetrad and vacuolated stages of microspores to almost completion on the first pollen mitosis with a major contribution from the tapetum (Fig. 2C). There are two major types of tapetum, the more primitive secretory type, considered to be the prevalent type in the majority of plants and the ameboid type that extends to the microspores in the anther locule for presumable direct delivery of tapetal contents (Fig. 2 A,C) (Furness and Rudall, 2001). The tapetum transfers sporopollenin and tryphine precursors to the pollen wall. Several typical lipid bodies, known as Ubisch bodies or orbicules, found on the fluid of the pollen sacs, were shown to accumulate at the site of exine formation on the surface of the developing microspores after completion of meiosis (Fig. $2 \mathrm{~B}, \mathrm{C}$ ). Its function remains elusive, but they are thought to be either a by-product of tapetal metabolism, or to have a direct functional role on transport of sporopollenin precursors (Heslop-Harrison, 1968a; Staiger and Apel, 1993). Recently, a structural protein named RAFTIN isolated in wheat and rice was shown to be essential for pollen development and it accumulates in Ubisch bodies targeted to microspore exine (Wang et al., 2003).

Angiosperm pollen walls consist of several layers of chemically different materials, an outer sporopollenin layer, the exine, which consists of two sublayers the sexine and the nexine and a pectocellulosic innermost layer, the intine (Fig. 2D).

Intine wall synthesis starts during the free microspore stage (Knox and Heslop-Harrison, 1970) presumably under gametophytic control (Fig. 2 B,C). The intine is composed of cellulose-like components, enzymes and other proteins like AGP-related glycoproteins (Knox and Heslop-Harrison, 1970; Vithanage and Knox, 1976; Vaughn, 1982; Dodds et al., 1993; Hiscock et al., 1994; Li et al., 1995; Aouali et al., 2001).

Exine formation begins with the synthesis of a cellulosic matrix, the primexine, which accumulates as a homogeneous layer 
between the plasma membrane and the callose wall of the microspore, except on areas destined to be pollen apertures (Fig. $2 \mathrm{~B}, \mathrm{C})$. The position of pollen apertures is believed to be set during microsporocyte cytokinesis (Heslop-Harrison, 1968b). The primexine precursors are synthesized and secreted by the microsporocytes to the pollen surface (Scott etal., 1991a; Fitzgerald and Knox, 1995) and may work as a scaffold for polymerization of fatty acids and phenolics on the surface (Sheldon and Dickinson, 1983; Scott et al., 1991a; Scott, 1994). The chemical composition of the exine is not exactly known, partly due to the high stability and chemical resistant composition of sporopollenin. Various biochemical analyses revealed a mixture of biopolymers of lipids, long chain fatty acids, phenylpropanoids, phenolics and carotenoids (Brooks and Shaw, 1968; Piffanelli et al., 1997; Piffanelli et al., 1998; Wang et al., 2002; Ahlers et al., 2003). Evans et al. (1992) have shown that a high rate of lipid biosynthesis in pollen grains start after PMI, later corroborated by the high expression levels observed in the tapetum for several enzymes related to lipid biosynthesis in Brassica napus (Piffanelli et al., 1997). The Arabidopsis male sterile ( $m s 2$ ) mutant produces non-viable pollen grains with very thin walls, lacking exine. The MS2 gene is suggested to encode a fatty acyl reductase which converts wax fatty acids to fatty alcohols, with expression observed in the tapetum shortly after the release of microspores from tetrads (Aarts et al., 1997). The mutant faceless pollen-1 (f/p 1), exhibits conditional male sterility and the FLP1 protein is likely to be involved in wax fatty acid biosynthesis required for the synthesis of tryphine, sporopollenin of exine and the wax components of stems and siliques (Ariizumi et al., 2003).

Enzymes of the phenylpropanoid pathway also show high levels on tapetal cells (Herdt et al., 1978; Shen and Hsu, 1992). Evidence supports the involvement of phenylpropanoids as components of sporopollenin (Guilford et al., 1988; Scott, 1994). In particular, high activity of chalcone synthase (CHS) and phenylalanine ammonia lyase (PAL) have been correlated with pollen fertility (Kishitani et al., 1993; Taylor and Hepler, 1997; Atanassov et al., 1998). Downregulation of PAL and CHS enzymes using antisense RNA, results in complete male sterility due to abnormal pollen development (van der Meer et al., 1992; Matsuda et al., 1996). An anther-specific transcriptional activator of $P A L$ (NtMYBAS ) was identified in tobacco and likely is a positive regulator of $P A L$ expression and phenylpropanoid synthesis in sporophytic, but not in gametophytic tissues of the anther (Yang et al., 2001). Silencing of the tapetum-specific zinc finger gene TAZ1 (tapetum development zinc fingerprotein 1) causes premature degeneration of the tapetum and pollen abortion in Petunia, with reduced flavonol accumulation, defects in pollen wall formation and poor germination (Kapoor etal., 2002). Similarly, the F3H gene, encoding a flavone-3-hydroxylase gene in Zea mays, was shown to be correlated with flavonol accumulation in anthers (Deboo et al., 1995). The expression of phenylpropanoid genes extends behind the completion of exine formation, indicating that they are also involved in other pollen structures (Shen and Hsu, 1992). However, flavonols may not be essential components of pollen grains in all species, since the flavonol-deficient Arabidopsis tt4 (transparent testa4) mutant, which disrupts the chalcone synthase gene known to catalyze the first step of flavonoid biosynthesis, shows normal pollen development (Burbulis et al., 1996; Ylstra etal., 1996). An alternative explanation to account for the fertility of Arabidopsis is the possibility that phenylpropanoids other than quercetin and kaempferol can compensate for a lack of flavonoids (Mitchell et al., 1970; Ylstra et al., 1992; Li et al., 1993; Ylstra et al., 1996).

Several mutants have been isolated in recent years, all affecting the exine. The Arabidopsis mutant, dex1n (defective in exine 1) is blocked in the normal invagination of the plasma membrane, which disrupts the proper deposition of sporopollenin, providing direct evidence for a critical role of the plasma membrane in the pollen wall pattern. $D E X 1$ is predicted to encode a membrane protein that contains several potential calcium-binding domains, which could act as nucleation sites for sporopollenin deposition (Paxson-Sowders etal., 1997; Paxson-Sowders etal., 2001). Two Arabidopsis male sterile mutants, $m s 9$ and $m s 12$, also show defects on exine deposition. In both, the tapetum degenerates earlier suggesting that the mutation may just affect general functions on the tapetum (Taylor et al., 1998). Lap1 (less adherent pollen 1), which shows a disturbed exine pattern, also presents defects on pollen adhesion to the stigmatic surface (Zinkl and Preuss, 2000).

In addition to the mechanical protection of the exine, a lipid-rich coat, termed pollen coat, pollenkit or tryphine, fills the spaces between the baculae of the exine surface and provides several important functions, such as attachment to pollinators, pollenstigma interactions, protection of pollen grains from excessive dehydration, UV-radiation or pathogen attack (Pacini, 1997; Zinkl et al., 1999; Dickinson et al., 2000).

Unlike exine, the pollen coat is easily extractable by organic solvents such as cyclohexane (Doughty et al., 1993). Brassica and Arabidopsis pollen coat has been intensively characterized (Doughty et al., 1993; Preuss et al., 1993; Ross and Murphy, 1996; Ruiter et al., 1997c; Murphy and Ross, 1998; Mayfield and Preuss, 2000; Mayfield et al., 2001; Fiebig et al., 2004), showing the presence of non-polar esters of medium and long-chain fatty acids, very long fatty acids (VLFA), small proteins and glycoproteins (Preuss et al., 1993; Piffanelli et al., 1997). Non-polar esters such as triterpene and sterol esters are thought to maintain the fluidity of the pollen coat in order to enclose and hold together proteins and other substances embedded in the pollen coat (Caffrey et al., 1987; Piffanelli et al., 1997). The long chain lipids of tryphine are known to be important during the initial contact with the stigma surface either by acting as signaling molecules themselves or by stabilizing/solubilizing other signal components on the pollen coat or cell walls (Wolters-Arts et al., 1998; Pruitt et al., 2000). Several eceriferum (cer) mutants in Arabidopsis, which eliminate very long chain lipids from the cuticle surface and, in some cases, from the pollen coat, are conditional male sterile. Pollen grains fail to hydrate when placed on the stigma, but are able to hydrate and grow a pollen tube in vitro (Preuss etal., 1993; Aarts et al., 1995; Hulskamp et al., 1995b; Jenks et al., 1995; Fiebig et al., 2000).

Although in species with wind-dispersed pollen the coat is highly reduced or absent, maize was used to characterize the two predominant proteins of the pollen coat. One is an endoxylanase and the other a $\beta$-glucanase. They are expressed in the tapetum and are thought to help pollen tube penetration by hydrolyzing the stigma cell wall (Bih et al., 1999; Suen etal., 2003). Some stigmas also present oleosins, which are thought to stabilize the lipids in the pollen coat during hydration and re-hydration and assist on 
adhesion of the pollen coat to stigma and subsequent hydration. In Brassica several glycine-rich oleosins were shown to be specifically expressed in the tapetum and their expression seems to be regulated by the water content in anthers (Ruiter et al., 1997a). Finally, mutant pollen from Arabidopsis deficient in one of the pollen surface glycine-rich proteins (GRP17) could undergo germination and fertilization although hydration on stigma was delayed (Mayfield and Preuss, 2000).

Lipases are also a major constituent of the Arabidopsis pollen coat and they were shown to alter lipid composition in vitro, making them putative mediators of pollen coat behavior (Mayfield et al., 2001). Similarly, non-specific lipid transfer proteins (LTPS), which are small, soluble, basic proteins from plants, are known to stimulate phospholipid transfer between membranes in vitro. They can bind to fatty acids and acyl-CoA esters and are thought to secrete or make the deposition of lipophilic substances in cell walls (Arondel et al., 2000). Several LTP proteins are expressed in the tapetum raising the possibility that these proteins may participate in the transfer of fatty acids and other lipid precursors from the tapetum to the microspores during pollen wall deposition.

The E2 gene encoding a LTP in Brassica napus is exclusively expressed in tapetal cells (Foster et al., 1992). In Arabidopsis the LTP1 protein is highly expressed in the cell walls of stigma and pollen grains. The $\angle T P 1$ promoter region contains sequences homologous to putative regulatory elements of genes in the phenylpropanoid biosynthetic pathway, suggesting that the expression of the $\angle T P 1$ gene may be regulated by the same or similar mechanisms as genes in the phenylpropanoid pathway (Thoma et al., 1994). In Zea mays the MZm3-3 gene was suggested to be involved in pollen coat formation. It encodes a short alkaline protein of $10.6 \mathrm{kDa}$ expressed in anthers with a conserved pattern of eight cysteine residues common to lipid transfer proteins and some male-flower-specific proteins (Lauga et al., 2000). Similarly, the LHM7 gene from Lilium henryi L. is anther specific and also contains the conserved pattern of cysteine residues present in non-specific lipid transfer proteins from Arabidopsis thaliana, Antirrhinum majus and Lycopersicon esculentum (Crossley et al., 1995).

Despite the new insights into the genetics and function of pollen coatings, the mechanisms by which these components are formed in the tapetum and translocated to the pollen grain surface and how they interact with the stigmatic surface remain far from clear.

\section{Gene expression on the male gametophyte}

The earliest efforts to dissect the molecular basis of pollen development relied on kinetic analysis of transcriptional and translational activity of anther-specific genes corresponding to different stages of pollen development. The first conclusive evidences that transcription and translation of the haploid genome during pollen development occur independently of the diploid tissues, were obtained from isoenzymatic profiles (Linskens, 1966; Weeden and Gottlieb, 1979; Stinson and Mascarenhas, 1985). In addition, detection of different classes of RNA after incorporation of labelled RNA precursors demonstrated an intense RNA synthesis associated with PMI, which resulted in an accumulation of RNAs upon anther dehiscence. In lily and Tradescantia the synthesis of ribosomal and transfer RNA was shown to occur prior to microspore mitosis, followed by a sharp decrease on synthetic activity leading to inactivation of transcriptional activity during the final stages of pollen development (Steffensen, 1966; Mascarenhas and Bell, 1970; Peddada and Mascarenhas, 1975). Despite these observations, protein synthesis is essential during pollen germination and pollen tube growth, suggesting that it is sustained by the presynthetized RNAs (reviewed by Mascarenhas, 1975). Interestingly, it has been shown in Tradescantia that a substantial amount of small molecular weight RNAs, which are not tRNAs, are synthesized upon pollen germination and tube growth (Mascarenhas and Goralnick, 1971).

The knowledge of pollen specific gene expression increased considerably through the use of differential and subtractive hybridization of cDNA libraries from isolated mature pollen grains of several species. Quantitative estimates of the amount of gene expression in the gametophyte generation and of the extent of gametophyte-sporophytic overlap were described (Stinson et al., 1987; Hanson et al., 1989; Brown and Crouch, 1990; Theerakulpisut et al., 1991; Weterings et al., 1992a). In maize, a major switch of gene expression after microspore mitosis was demonstrated by differences on the mRNA populations isolated from different developmental stages (Bedinger and Edgerton, 1990). Mandaron et al. (1990) used in vivo labelling and twodimensional gel electrophoresis to show that protein synthesis was extremely active from tetrad stage to the vacuolated stage of pollen development, stopped for a short period during starch accumulation and rapidly increased just before anther dehiscence, indicating that presumably these proteins were required for pollen germination and tube growth.

All these results established the foundation for the generally accepted concept that pollen development is transcriptionally modulated. RNA populations and protein profiles of several species showed that specific mRNAs could be associated with pre- and post-mitotic stages, sustaining the view proposed by Mascarenhas (1990), that two classes of genes were expressed during pollen development. Transcripts from the "early" genes, which are detected soon after meiosis and are reduced on mature pollen grains and transcripts of "late" genes, which are first detected soon after PMI and continue to accumulate as pollen matures, create a stable pool of mRNA thought to be essential for germination and early pollen tube growth. Thus, at the time of anthesis, all the proteins that are required for germination and early tube growth are either already in the pollen grain, or if new, the messenger RNAs for their synthesis already exist in the ungerminated pollen grain. The genetic program of the latter part of pollen maturation prior to anthesis should then be the same as the one present during germination and tube growth.

Because most of the research has been done on pollenspecific genes expressed after pollen mitosis, few transcripts of the so-called "early" genes were isolated. The undifferentiated state of the microspore before mitosis may constitute a reason for the difficulty in isolating microspore-specific genes. A differential screening of cDNA libraries covering the stages of anther development from pre-meiotic microsporocytes to tri-nucleate pollen grains led to the isolation of several microspore-specific clones from Brassica napus (Scott et al., 1991b). The Bp4 gene in Brassica napus is expressed from the early unicellular microspore stage until the tricellular stage (Albani et al., 1990). In 
situ hybridization of the NTM19 transcript of Nicotiana tabacum was only detected in the unicellular microspore (Oldenhof et al., 1996). However, the expression of the GUS ( $\beta$-glucuronidase) reporter gene under the control of Bp4 and NTM19 promoters in a heterologous system (Nicotiana tabacum) demonstrated that the $B p 4$ promoter becomes active after the first pollen mitosis, but not in the microspores. However, the NTM19 promoter turned out to be microspore-specific and to direct very high levels of GUS expression in unicellular microspores. These results showed the NTM19 promoter as an excellent tool to direct high levels of transgene expression exclusively to the microspores (Custers et al., 1997).

A good example of the "late" pollen genes, are the $L A T$ ( Late Anther Tomato ) genes isolated from Lycopersicon esculetum, which have been intensively characterized in the last years. The $\angle A T 52$ and $\angle A T 51$ genes encode for cysteine-rich proteins and the LAT56 and LAT59 show sequence similarity to pectate lyase proteins, all presumably involved on late stages of pollen development (Twell et al., 1989; Ursin et al., 1989). Conclusive evidence of a vegetative cell-specific regulation was obtained for $\angle A T$ genes by linking the gene promoter sequences to a GUS reporter gene (Twell et al., 1991; Twell, 1992; Eyal et al., 1995; Bate et al., 1996). The LAT52 promoter was able to confer a dramatically increased expression of heterologous transcripts in a pollen-specific and strictly developmentally regulated manner during the final stages of pollen maturation and thus turned out to be a suitable promoter to direct transgene expression in mature pollen grains of dicots. Since then it has been widely used in numerous studies (Muschietti et al., 1994; Liu et al., 1999; Gerola et al., 2000; Cheung, 2001; Faure et al., 2002; Cheung et al., 2003). Several other late genes showing a similar pattern of expression were isolated from several species. In some of them the promoter regions share considerable homology with regulatory elements of $L A T$ promoters (Hanson et al., 1989; Guerrero etal., 1990; Albani etal., 1991; Hamilton etal., 1992; Lombardero et al., 1994; Weterings et al., 1995; Hamilton et al., 1998).

Due to their size, sperm RNA is likely to be diluted on the total pollen RNA and thus poorly represented in EST databases. This called for sperm or generative cell cDNA libraries as a way of identifying specific transcripts. The approach was first taken on species where the relative large size of the pollen grain would facilitate generative cell isolation. The $\angle G C 1$ gene was isolated from a cDNA library of lily generative cells and was shown to be expressed exclusively at the surface, suggesting a possible role in sperm-egg interactions (Xu et al., 1999). Moreover, analyses of the LGC1 promoter have shown a regulatory sequence required to direct gametic cell-specific expression (Singh et al., 2003). Recently thousands of cDNA clones isolated from a sperm-cell cDNA library of Zea mays revealed the presence of a large diversity of mRNAs (Engel et al., 2003). Most of the sequences are predicted to encode secreted or plasma membrane localized proteins and a large number of transcripts of unknown function, representing potential good candidates to mediate gamete interactions. However, some sperm transcripts were found to be expressed in late microspores and hence could be present on the vegetative cell as well. The authors suggest that certain transcripts may be transcribed early in pollen development and later directed into sperm cells.

\section{A transcriptomic definition of pollen}

Despite all the approaches described on the previous paragraph, the genetic basis of pollen development and pollen germination and tube growth was restricted to a total of about 150 pollen-expressed genes in about 28 species (Twell, 2002). The development of technologies allowing true large-scale gene expression profiling has paved the way for the comparison of the transcriptome of the male gametophyte with the transcriptional profiles of sporophytic tissues, which revealed the unique features of the transcriptome of mature pollen grains. Five recent studies used Arabidopsis thaliana with two different technologies. While Lee and Lee (2003) used Serial Analysis of Gene Expression (SAGE) technology, two other groups employed GeneChip technology (Becker et al., 2003; Honys and Twell, 2003; Honys and Twell, 2004; Pina et al., 2005). The five studies come to similar general conclusions, but differences arise due to the technology used and the different experimental approaches.

In a first approach Becker et al. (2003) and Honys and Twell (2003) used Affymetrix AG GeneChip arrays, which represented approximately 8,200 genes and thus almost one third of the Arabidopsis genome (reviewed in da Costa-Nunes, 2003). Both groups compared the transcriptional profile of mature pollen grains to those of sporophytic tissues, but there were significant differences in the number of pollen-expressed genes $(1,584$ versus 992) and of genes predicted to be selectively expressed in pollen (10\% versus $40 \%$ ). The discrepancy for pollen-selectively expressed genes most probably derived from the differences of sporophytic tissues chosen for comparison. While we compared the transcriptional profile of pollen to those of seedlings, leaves, roots and siliques, Honys and Twell (2003) used developmental stages instead. The latter approach could cause a dilution effect of individual tissues expression patterns and therefore increase the proportion of putatively pollen-selective genes. Discrepancies in pollen-expressed genes and relative expression values between the two studies might also derive from the fact that we developed a protocol for fluorescence activated cell sorting (FACS) of Arabidopsis pollen grains to assure that only highly purified, viable pollen grains were used for the extraction of total RNA and in addition a specialized normalization protocol for the GeneChip raw data sets that accounts for the relatively small number of genes expressed in pollen, when compared to the vegetative tissues (Becker et al., 2003). We believe that cell sorting is important, not only to avoid that RNA from non-pollen cells is included in the pollen sample, but also because autolysis, observed in mature Arabidopsis pollen grains (Yamamoto et al., 2003), bears the risk of including non-viable pollen with altered RNA levels and ongoing RNA degradation in the sample. The fact that different Arabidopsis ecotypes where used in the two studies (Columbia and Landsberg erecta) might also explain differences between the results obtained. Phenotypic differences between ecotypes and proteome analysis (Chevalier et al., 2004) raise doubts on the value of direct comparisons of transcriptional profiles derived from different Arabidopsis ecotypes. This notion is supported by recent studies using ATH1 arrays to compare the transcriptomes of vegetative shoot apices from $\mathrm{Co}$ and $\mathrm{Ler}$, which indicates many genuine expression differences between these two ecotypes (Schmid et al., 2003).

Besides the differences in the two studies by Becker et al. 
(2003) and Honys and Twell (2003), a general picture of the unique characteristics of the pollen transcriptome emerged. This included a reduced complexity when compared with the sporophyte and a relative over-representation of mRNAs in pollen encoding proteins involved in signalling, cell wall metabolism and cytoskeleton dynamics, contrasted by an under-representation of mRNAs related to energy pathways and translation. These studies comprised an important first step to a better understanding of pollen tube growth and morphogenesis by providing hundreds of new transcripts of potential importance.

The introduction of the ATH1 GeneChip array (Redman et al., 2004) allowed the enlargement of the studies to a nearly fullgenome scale, covering more than $80 \%$ of the Arabidopsis genome. Pina et al. (2005) compared the transcriptional profile of cell-sorted, mature pollen grains with those of seedlings, flowers, leaves and siliques ( $A$. thaliana ecotype Columbia), while Honys and Twell (2004) have analyzed male gametophyte development in $A$. thaliana ecotype Landsberg erecta from uninucleate microspores (UNM) over bicellular (BCP) and tricellular (TCP) pollen to mature non-sorted pollen grains (MPG) in comparison with publicly available sporophytic datasets. In another approach, Lee and Lee (2003) used SAGE to profile the transcriptome of mature pollen ( $A$. thaliana ecotype Columbia) under normal and chilling conditions and in comparison to leaves. The number of identified genes expressed in mature pollen grains ranged from 4,211 in the SAGE study over 6,587 genes in cell-sorted pollen grains to 7,235 genes in non-sorted pollen grains. The significantly lower number obtained in the SAGE study surprises, since this technology does not require prior knowledge of the transcripts and can thus discover previously unknown transcripts, which would not be detected on the ATH1 GeneChip. However, a possible explanation for the lower number is that only the limited amount of 21,237 tags were obtained and sequenced, which in the authors' estimate should have allowed them to detect transcripts present at a minimum of 5 copies per cell $(1 / 20,000$ transcripts). In addition, the use of relatively short $10-\mathrm{bp}$ sequence tags in this study complicates the unique assignment to specific genes, particularly when members of a gene family have a high degree of similarity (tag-to-gene ambiguity, reviewed in Meyers et al., 2004). The detection sensitivity of Affymetrix GeneChips is approximately $1 / 100,000$ transcripts and with 11 probe sets representing each transcript most of the even highly homologous sequences can still be distinguished. Thus the number of 6587 different transcripts being expressed in Arabidopsis pollen based on our study should be more reliable (Pina et al., 2005). An extrapolation to the 28,000 genes encoded in the Arabidopsis genome, would lead to an estimate of about 8,200 transcripts stored in mature pollen grains.

The study by Honys and Twell (2004) reveals the remarkable decline in diversity of mRNA transcripts during the development of the male gametophyte, which is most prominent during the transition from bicellular to tricellular pollen. According to their analysis the transcript diversity slightly increases from 11,565 in microspores to 11,909 different transcripts in tricellular pollen and then drops to 8,788 and 7,235 different transcripts expressed in tricellular and mature pollen, respectively. However, these numbers should be used in perspective for two reasons. Firstly the purity of several stages of the isolated microspores was suboptimal, ranging from $95 \%$ for UNM over $77 \%$ for BCP to $88 \%$ for
TCP. With the sensitivity of the ATH1 GeneChip estimated at 1 transcript per cell (Redman et al., 2004), transcripts with medium and high expression levels in the impurities will be detected as present. In other words, genes expressed at medium or high levels in bicellular and not in tricellular pollen will have been detected on the TCP GeneChips, because of the $12 \%$ of bicellular pollen contained in the tricellular pollen sample. Thus the decline in diversity of transcripts from bicellular to tricellular pollen is most probably underestimated. Secondly, during the data analysis the empirical MAS 4 detection algorithm was used to determine present and absent calls for all GeneChip raw data sets (Honys and Twell, 2004), which yields more false positive calls in comparison to the statistical MAS 5 detection algorithm (Liu et al., 2002). We re-analyzed the data sets for the male gametophyte (J.D. Becker, unpublished) using DNA-Chip Analyzer 1.3, the MAS 5 algorithm for detection calls and the relatively stringent criterion used by Honys and Twell (2004) of calling only genes as Present (expressed), when they were called Present in both replicates; this stringency seems justified with regard to the impurities mentioned and the relatively low correlation of the replicates, especially for BCP and MPG. Based on 22,750 genes being represented on the ATH1 GeneChip, our re-analysis identified 9390 different transcripts to be expressed in UNM, 9,602 in BCP, 6,788 in TCP and 5,075 in MPG. 11,405 genes were expressed in at least one stage of male gametophyte development. Since Honys and Twell (2004) identified 13,977 malegametophyte expressed genes, the difference of 2568 genes could be seen as potential false positives. The comparison of the gametophytic data set ( $L a n d s b e r g$ erecta) with sporophytic ATH1 data sets derived from the ecotypes Columbia, Wassilewskija and $C 24$ adds further complications to this study. Yet, this pioneer study provides a good general overview of the transcriptome changes occurring during the development of the male gametophyte.

The specialization of the male gametophyte transcriptome after pollen mitosis II (PMII) can also be seen in a reduction of the number of diverse transcripts comprising the high abundance class, while at the same time genes related to cytoskeleton, cellwall and signaling become over-represented in this class. The transition from early to late developmental programs was further analyzed by using cluster analysis, a powerful tool to detect sets of co-regulated genes in time-course data sets. As expected, major clusters containing genes repressed after PMII were identified. Those clusters containing genes up-regulated after BCP/ TCP stage should contain genes of importance during pollen germination, tube growth and fertilization. Focusing on genes with potential regulatory roles in the male gametophyte, Honys and Twell (2004) showed that for most of the core translation factors expression is restricted to the early stages. Surprisingly, against this trend, 6 of 7 transcripts encoding poly(A)-binding proteins are expressed in mature pollen grains, some specifically. The analysis of 608 transcription factors (412 after our re-analysis), showed clusters containing transcripts with early, constitutive and late expression throughout development of the male gametophyte. Those transcription factors showing high expression levels in mature pollen grains are of special interest, because studies in several plant species have indicated that the bulk of mRNA needed for pollen germination and early tube growth is stored in mature pollen grains (Mascarenhas, 1989; Guyon et al., 2000; 
Wang" et al., 2004). Honys and Twell (2004) confirm this strict dependence on translation, but not transcription, for Arabidopsis thaliana pollen by using translational and transcriptional inhibitors in pollen cultures. However, their criterion to score pollentube growth was that tubes had to be longer than two pollen grain diameters. Thus their study does not allow conclusions on what effect a block of transcription will have on pollen tube growth in later stages. It is likely that at least some of the transcription factors up-regulated in mature pollen grains are involved in"de novo transcription during pollen tube growth. This idea is supported by differential screens for cDNAs up-regulated or induced after pollen germination in Petunia (Guyon et al., 2000), de novo synthesis of mRNAs depleted after cold-storage in lily pollen (Wang etal., 2004) and by an initial study comparing the transcriptional profiles of Arabidopsis pollen grains and in vitro grown pollen tubes using ATH1 GeneChips (Miyazaki et al., 2004).

We compared the transcriptomes of pollen and vegetative tissues of the same ecotype (A.t. Col-0 seedlings, leaves, siliques and flowers) using graphical "Snail-view" representations and Principal Component Analysis to underline the distinctiveness of the pollen transcriptome (Pina et al., 2005). Based on these comparisons we identified $11 \%$ of the 6587 genes expressed in mature pollen grains as pollen selectively expressed. Mature pollen grains have not only greater proportions of selectively expressed genes, but also more enriched genes (26\%) than any vegetative tissue, confirming previous conclusions from other groups (Lee and Lee, 2003; Honys and Twell, 2004).

Can this relative specialization of the pollen transcriptome be linked to the biological functions of pollen, namely germination, pollen tube growth and fertilization of the female gamete? The three studies come to similar conclusions: using Gene Ontology (GO) terms and adding an analysis of statistical significance we looked at the frequencies of representation of GO categories in the different tissues (Pina et al., 2005). Transcripts encoding proteins in the classes signalling (reviewed in Feijó et al., 2004), vesicle trafficking, cytoskeleton and membrane transport were proportionally over-represented, a tendency also observed in male-gametophyte specific genes during microsporogenesis (Honys and Twell, 2004). These classes become even more prominent when analyzing the functions of pollen-enriched genes (Lee and Lee, 2003; Pina et al., 2005). On the contrary, the functional classes transcription, protein synthesis (e.g. ribosomes) and general and oxidative metabolism are under-represented in mature pollen grains. Although the protein synthesis class is under-represented, translation initiation factors are enriched in pollen (Pina etal., 2005), supporting the notion that an mRNA pool ready for rapid translation upon re-hydration is stored in mature pollen.

A detailed view on gene families and pathways in Arabidopsis pollen has become possible due to the extensive representation of transcripts of gene families and pathways on the ATH1 array. As an example expression data for mature pollen grains compared with an average of vegetative tissues are overlaid on a map of general metabolism in Arabidopsis (Fig. 3A). In accordance with results of the GO analyses, a high proportion of genes involved in cell wall and lipid metabolism are up-regulated and the opposite was found for transcripts involved in energy metabolism. While the absence or down-regulation for transcripts of light reactions and photorespiration is anticipated, the same tendency is found in processes like glycolysis and mitochondrial electron transport. Considering the fast growth rate of pollen tubes, how the energy needed is provided becomes an imminent question.

A detailed analysis of transcription factor families hints at an important role for non-classical MADS-box genes, showing an over-representation of pollen-expressed and enriched genes (Fig. 3B). Interestingly, some of these non-classical type I and MIKC* genes have also been detected as specifically expressed during reproductive development in a recent study using ATH1 GeneChips to profile three stages of Arabidopsis flower and fruit development (Hennig et al., 2004). As the authors note, their set of identified floral-specific genes is dominated by genes expressed in pollen. The exact functions of the non-classical MADS -box genes are not understood and MADS-box genes are not the only class of transcription factors with enriched transcripts in pollen. We combined and re-analyzed data sets on microgametogenesis with our comparative analysis with the restriction of different ecotypes being used in these studies. As a result, we identified transcription factors up-regulated during the development of the male gametophyte that show at the same time higher expression levels in mature pollen, when compared with vegetative tissues (Fig. 3B and Table 1). These transcription factors might be the ones controlling de novo transcription in pollen germination and thus should constitute possible primary targets for reverse-genetic approaches.

Pollen might not only serve as a model to study cell growth and morphogenesis, but also, by omission, of cell cycle control. The vegetative nucleus of pollen is thought to be arrested in $\mathrm{G} 1$ of the cell cycle. Again, we have used a combination of pollen expression data with a recent schematic overview of the mechanistic regulation of the G1-S and the G2-M transition in plants (Pina et al., 2005), which indicates that the block is achieved by a combination of absence of transcripts encoding essential proteins for the G1-S transition (CycD, E2F-DP) and an up-regulation of potential repressors (DEL3) and of potential factors of increased cell-cycle duration (CKS2). Surprisingly, pollen seems to feature most of the transcripts needed for the G2-M transition, though probably kept in their inactive state through a relative down regulation of the CDC25 phosphatase. In support of these results, Hennig et al.(2004) have come to the conclusion that S-Phase genes were under-represented and G2/M-Phase genes enriched in the set of genes they identified as specifically expressed during reproduction. In the light of G2 karyogamy in Arabidopsis this might indicate a key role for pollen derived transcripts or proteins during the first mitosis after fertilization, although it is unclear how the transcripts or proteins would get to the egg cell unless they are somehow accumulated in the sperm cells.

A surprising finding was the apparent inactivation of small RNA pathways in mature pollen (Pina et al., 2005). The analysis of the expression of genes involved in small RNA pathways in Arabidopsis revealed that all of the 15 transcripts analyzed, including those encoding Argonaute 1,2,4 and 7, Dicer-like 1-3 and RNA-dependent RNA polymerase 1,2 and 6, were called Absent in pollen, while the majority of them were expressed in the vegetative tissues. In addition, a specific down regulation of these transcripts occurs during microgametogenesis. The apparent absence of small RNA pathways in Arabidopsis mature pollen would affect all small RNA pathways known in plants (Baulcombe, 2004), including the defence against viruses through siRNAs, the regulation of 
A
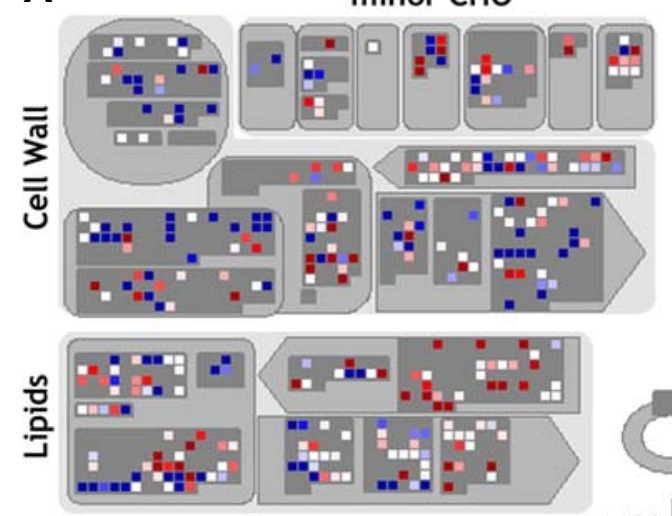
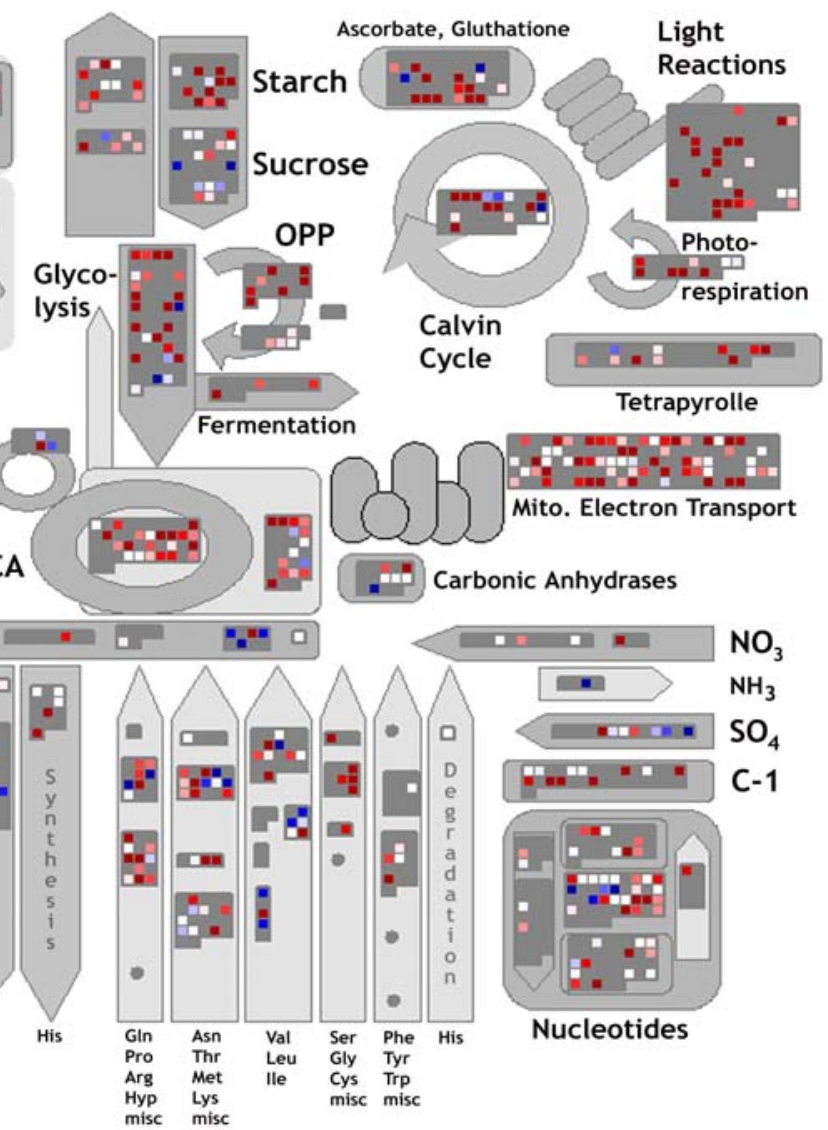

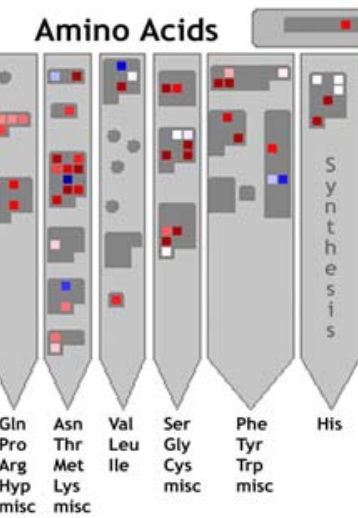

B

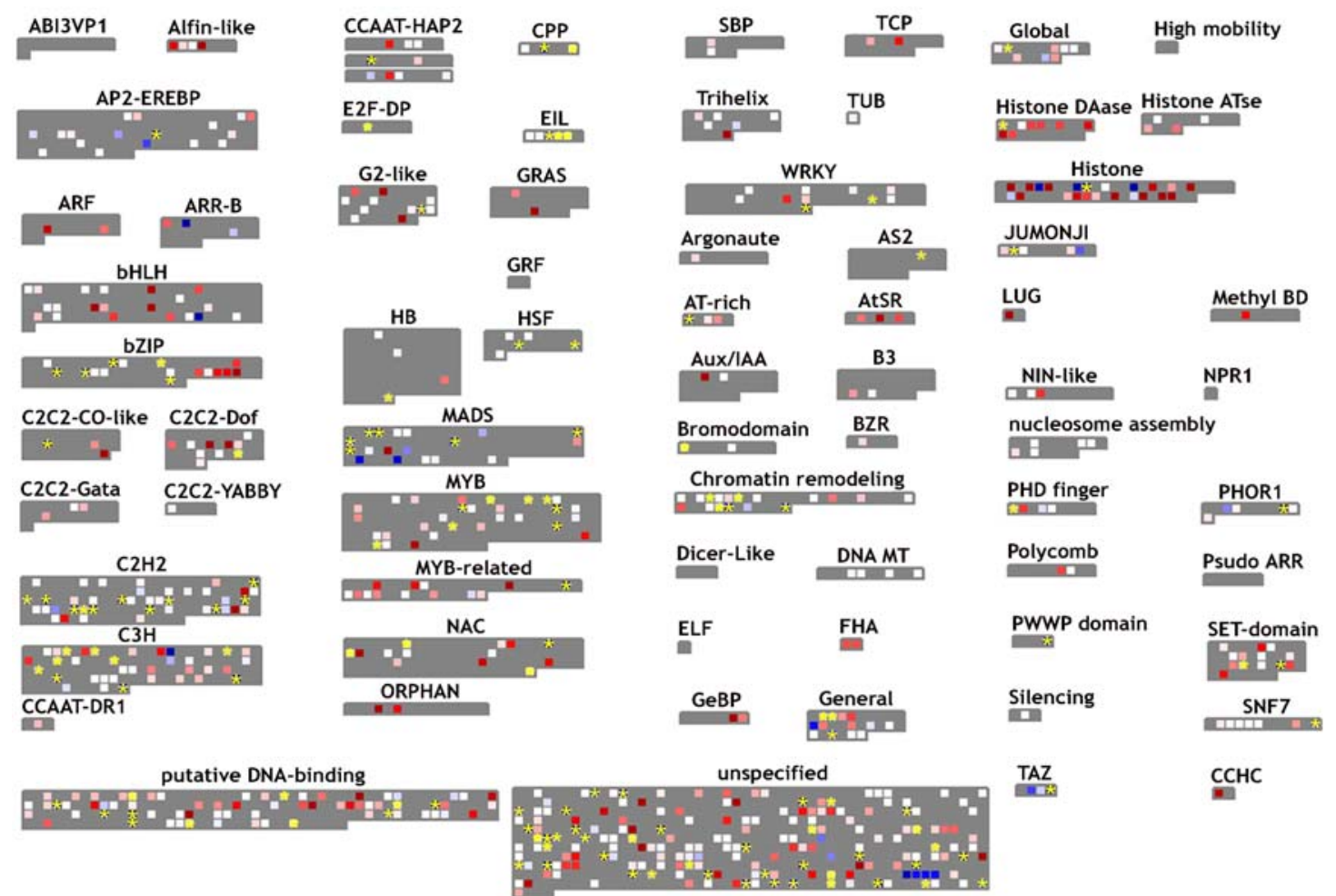

Fig 3. Expression patterns for general metabolism and transcription in the pollen transcriptome. (A) Gene expression data in pollen relative to the vegetative tissues leaves, seedlings and siliques Igenomic data set derived from the study of Pina et al., (2005) are depicted in an overlay on a map of general metabolism in Arabidopsis using the MAPMAN tool (Thimm et al., 2004). Genes are symbolized by color-encoded squares (red, down-regulation; blue, up-regulation; white, Present call in pollen, but no change; grey, Absent call in pollen).

(B) Gene expression data in pollen relative to the vegetative tissues on a map of genes involved in transcription in Arabidopsis. Genes are symbolized by color-encoded squares (red, down-regulation; blue, up-regulation; white, Present call in pollen, but no change; grey, Absent call in pollen). In addition those genes showing an up-regulation in this comparison and during Arabidopsis microgametogenesis (mature pollen versus uninucleate microspores; re-analyzed data set of (Honys and Twell, 2004) are marked with yellow asterisks and their detailed expression data are listed in table 1 lexcept for the groups "putative DNAbinding" and "unspecified"). 
gene expression through miRNAs and the condensation of chromatin into heterochromatin. This absence of small RNA pathways in mature pollen would provide new possible explanations for genetic and epigenetic phenomena found in the male gametophyte and during/after fertilization.

Though not on a genomic scale, smaller studies in other species, e.g. like those on Petunia (Guyon et al., 2000; Cnudde et al., 2003) and lily (Wang et al., 2004), are complementing the Arabidopsis data sets and reveal new aspects of pollen genetics and physiology. Transcriptomic studies are providing a quantum leap in information available for the male gametophyte.

\section{The female reproductive organ- pistil and ovule devel- opment}

Thorough descriptions of the molecular and genetic basis of the female organ development Arabidopsis can be found in recent reviews (Gasser et al., 1998; Skinner et al., 2004).

Unlike in other groups of plants, ovules in Angiosperms are enclosed within a carpel and during seed development they produce an embryo-nourishing endosperm (Friedman, 2001b). The evolution of a closed carpel (syncarpy) is believed to be one of the major evolutionary changes, which led to the reproductive success of angiosperms. Carpels are proposed to have evolved from ancestral foliar organs or bract-like structures (Bowman et al., 1999). Carpels may be associated or not in the pistil, or gynoecium, which is the female reproductive unit of the angiosperm flower. Pistils differ widely in form between species (Endress and Igersheim, 1999). Despite the differences in the overall morphology, a set of common structures, characterized by cell types with unique properties, can be distinguished. In Arabidopsis, at maturity, most gynoecia are composed of (1) a basal ovary, usually with fused carpels, which encloses the ovules bearing the female gametophyte, (2) a short solid style, which places the stigmatic surface in close contact with the anthers and (3) an apical stigma composed of numerous elongated epidermal cells, where pollen grains adhere and germinate (Sessions and Zambryski, 1995; Bowman et al., 1999). The style varies in length and appearance in association with specific pollination strategies (Barrett, 2002). The transmitting tract is a special layer of cells, which originates in the stigma and spans the entire organ, secreting a mucilaginous extracellular matrix. After fertilization a prominent elongation of the ovary precedes the dispersal of the mature seeds (Ferrandiz etal., 1999).

In Arabidopsis pistil development starts with a ring-shaped primordium by stage 6 of flower development. The gynoecium continues to elongate and develops as an open cylinder with a medial ridge, where the placental and septum will form (Fig. 4 A,B ). At stage 9, rows of ovules arise from the placental tissue along the margins of the site of carpel fusion, the septum. By stage 10 the septum is formed, resulting in a gynoecium with two congenitally fused carpels. At stage 11, the stigmatic papillae differentiate and ovules develop a funiculus and integument. At stage 12 the gynoecium grows, the transmitting tract differentiates and ovules are completed. Stage 13 defines anthesis, the gynoecium comes to maturity and the flower opens (Smyth et al., 1990; Sessions, 1997; Ferrandiz et al., 1999).

Ovules are simple structures, which consist of three elements: at the top, the nucellus harbors the haploid embryo sac or female gametophyte, a central chalaza, which is characterized by the integuments initiating at its flanks and at the bottom and the funiculus or stalk that connects the ovule to the carpel tissue (Fig. $4 \mathrm{G})$. The ovules are initiated from divisions occurring in the subepidermal tissue of the placenta and cell proliferation gives rise to finger-like structures that will differentiate in an ovule (Fig. $4 \mathrm{C}$ E) (Jenik and Irish, 2000). The integuments are two cell layers that will give rise to the seed coat. They cover the nucellus, forming the mycropyle, a small aperture through which the pollen tube will penetrate (Fig. 4G). The outer integument grows asymmetrically, shaping the typical curvature to the ovule (Fig. 4G).

Identically to other floral organs, ovule identity is regulated by MADS-box genes. In tobacco the two mutants Mgr3 and Mgr9 have carpelloid structures instead of ovules and in Petunia the cosuppression of the two genes FLORAL BINDING PROTEIN7 ( $F B P 7)$ and $F B P 11$ resulted in a similar phenotype (Evans and Malmberg, 1989; Angenent et al., 1995). Furthermore the ectopic expression of $F B P 11$ led to ectopic ovuloid expression (Colombo et al., 1995). The identification of these and many other flower organ mutants contributed to elucidate much of the molecular and genetic mechanism of floral organ development, but it should be kept in mind that many of these mutants show pleiotropic effects in early stages of flower development and thus the elucidation of their true effects may be partially disguised.

\section{The female gametophyte - the embryo sac}

The female gametophyte supports pollen tube growth down to the ovule, directing the sperm cells to the egg cell and central cell, up to seed, embryo and endosperm development (Chaudhury and Berger, 2001; Chaudhury etal., 2001; Higashiyama, 2002; Johnson and Preuss, 2002; Higashiyama et al., 2003). Sporophytic mutations characterized by female sterility, such as megaspore mother cell development and meiosis are developmental processes originated in the surrounding sporophytic tissues (Gasser et al., 1998; Grossniklaus and Schneitz, 1998). On the other hand, systematic screens based on two essential criteria, abnormal seed set and distorted Mendelian segregation, identified a number of gametophytic mutations disrupting distinct steps of embryo sac ontogenesis in Arabidopsis and maize, indicating the requirement of haploid expressed genes (Christensen et al., 1997; Drews et al., 1998; Siddiqi et al., 2000; Christensen et al., 2002).

The ovule primordium initiates as an outgrowth that emerges from the carpel placental tissue (Fig. 4 B-F). Megasporogenesis begins with the differentiation of an archeosporial cell in the hypodermal cell layer at the distal end of the nucellus (Fig. 4D). Usually only a single cell differentiates. In the mac1 mutant of maize several hypodermal cells develop into archeosporial cells, suggesting that this gene may be required to suppress the differentiation in neighboring cells and putatively controlling the switch of the hypodermal cells from vegetative to meiotic (Sheridan et al., 1996). In general, megasporogenesis in Arabidopsis involves the differentiation of one of these cells in the megaspore mother cell (MMC) in the nucellus, which undergoes meiotic reduction giving rise to four haploid nuclei (Fig. $4 \mathrm{~A}, \mathrm{C}-\mathrm{E}$ ). SPOROCYTELESS $(S P L)$ blocks the transition from archeosporial cell into a megasporocyte in ovules (Yang et al., 1999). These defects may be related with the lack of support and nutrient supply to the female gametophyte (Reiser et al., 1995; Elliott et al., 1996; Klucher et al., 1996). In agreement with the role of integuments in the control of 


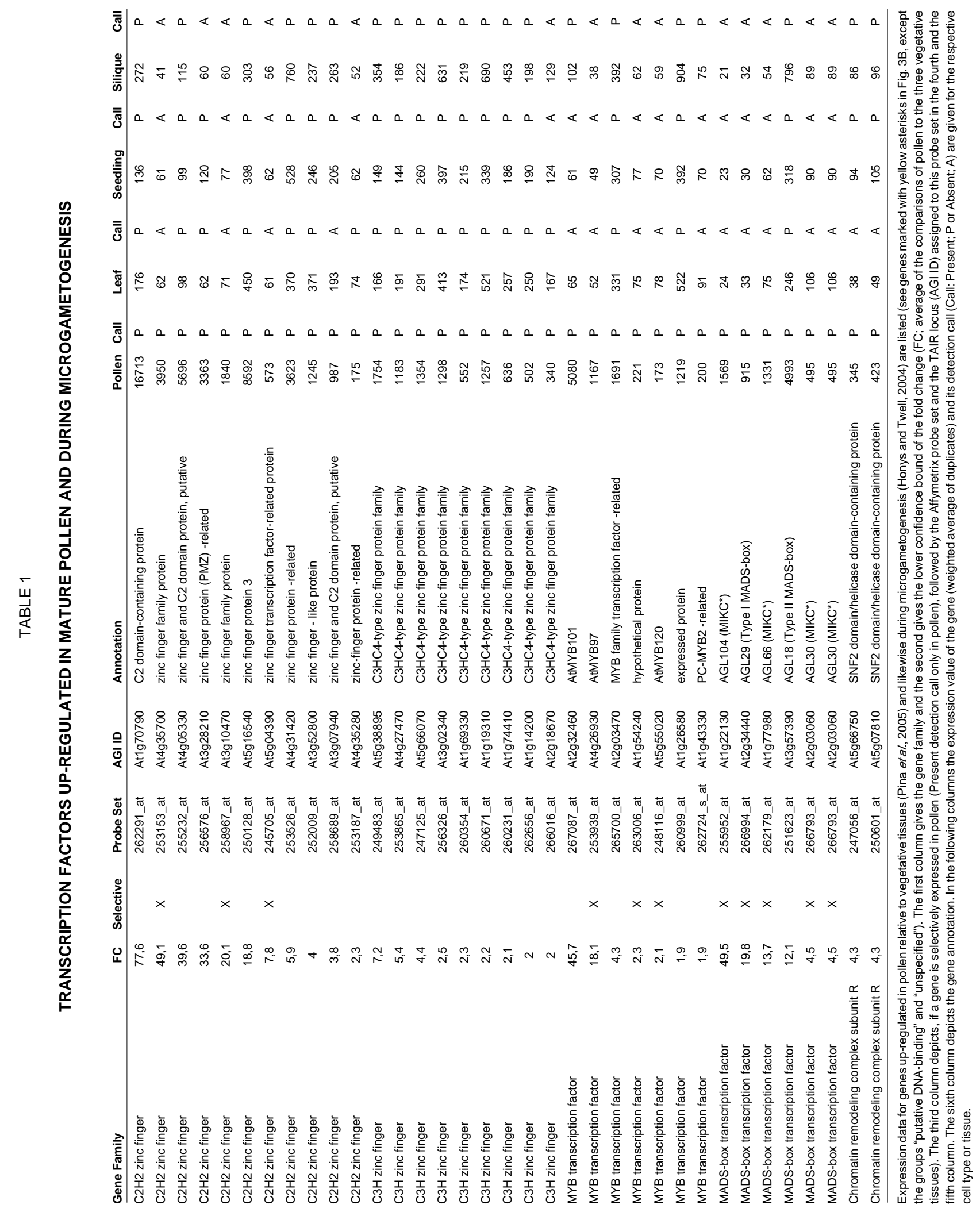


A
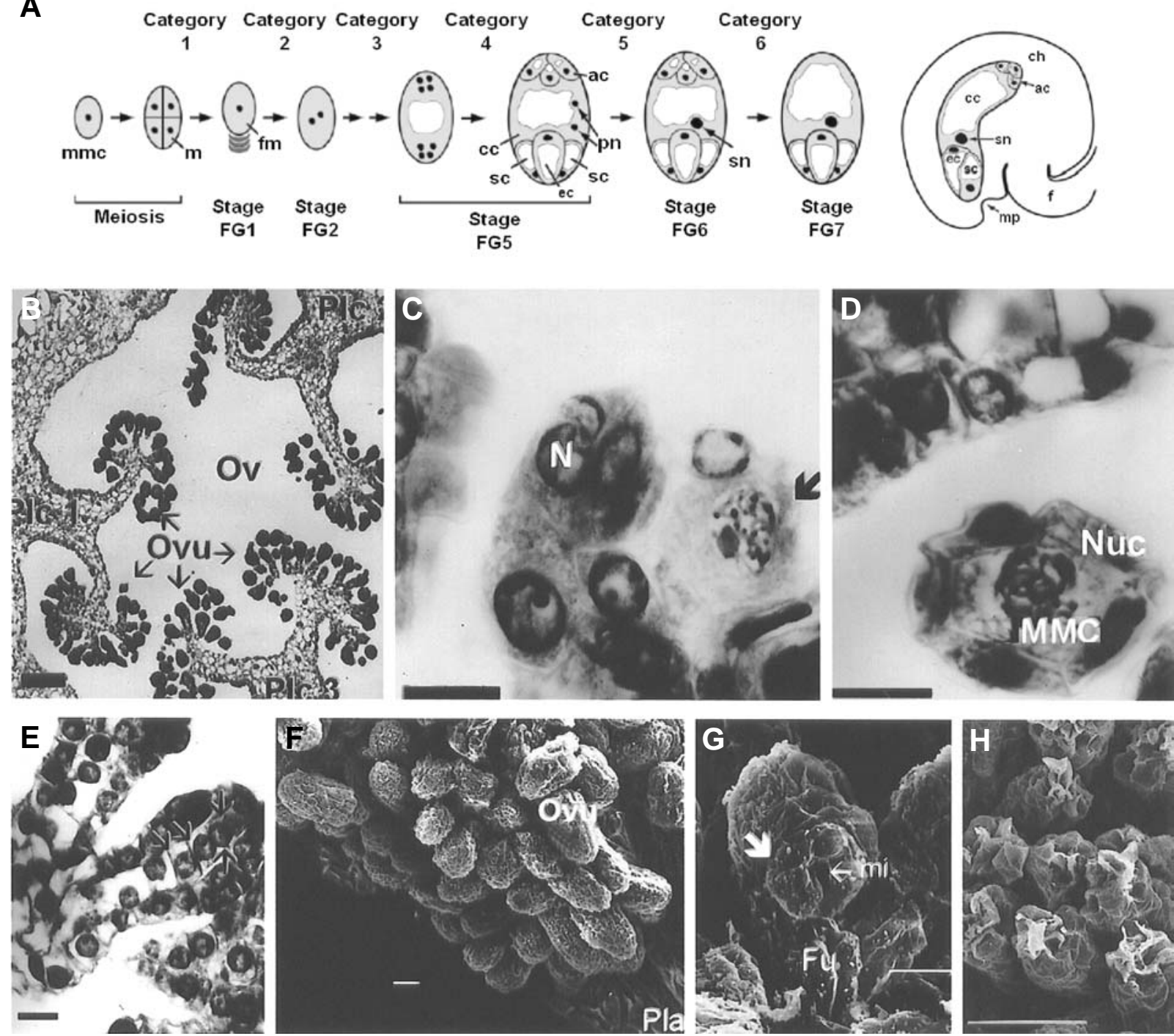

Fig. 4. The development of embryo sac and the ovule. (A) Major events on embryo sac ontogeny. Categories represent checkpoints on embryo sac development based on mutant analysis. mmc megaspore mother cell; fm female megaspore;CC central cell; EC egg cell; SC synergid cell; pn polar nuclei; ac antipodal cell; sn secondary nucleus; ch chalaza; mp mycropyle; f funiculus. Adapted from Drews et al. (1998) and Yadegari and Drews (2004).

(B-E) Embryo sac development in O. lutea. The ovary is divided by 3 parietal placentas (B). The apical cell of the nucellus (N or Nuc) divides longitudinally (C) and then anticlinally to define a central megaspore mother cell (MMC), that enters meiosis (arrow in (C,D)). This cell gives rise to a linear tetrad (arrows in (E)), 3 of which will regress and the top one will develop into the mature embryo sac, like depicted in (A) (category 3 on). (F-H) Ovule development. From a capsule like shape (F) ovules (OV) bend over by differential growth of the integuments to form a pipe-like structure (G). At this stage the integuments also grow to form the pollen tube entry point, the micropyle (mi). At later stages of mature ovules, the micropyle is sometimes covered with secretion $\mathbf{( H )}$.

meiotic progression is the sterile apetala (sap) mutant, where megasporogenesis is arrested during or just after meiosis. Although the $S A P$ gene is expressed initially in the nucellar region, it switches to a prominent integument expression later on (Byzova et al., 1999). The DYAD gene was reported to be female specific and meiosis is arrested at the dyad stage (Siddiqi et al., 2000). The four haploid cells are surrounded by a very thin cell wall after meiosis, with plasmodesmata connecting the chalazal megaspore to the neighbouring nucellar cells, suggesting that it may provide a positional signal that promotes the degeneration of the other spores to undergo cell death. At the beginning of meiosis in
Arabidopsis the MMC shows cytoplasmic polarity, thought to be important to determine the functional megaspore (Bajon et al., 1999).

Megagametogenesis begins when the surviving megaspore goes through three rounds of mitosis to form a two-nucleated, fournucleated (Fig. 4E) and subsequently eight-nucleated embryo sac (Fig. 4A; stage FG1-FG4). Different patterns of gametophyte development have been described in several species, differing from each other by variations on cytokinesis during meiosis, on the number of mitotic divisions and on the cellularization pattern. Arabidopsis and maize megasporogenesis follows the monosporic 
Polygonum type, which is also the most common form in Angiosperms (Maheshwari, 1950; Willemse and van Went, 1984; Huang and Russell, 1992a). At the end of each meiotic stage vacuoles occupy a central location on the cells and microtubules are thought to mediate nuclear migration to position the nuclei at the poles of the coenocytic cell (Webb and Gunning, 1994a). After the third mitotic round non-sister nuclei and the embryo sac begin to cellularize to form the final seven-cell structure. The other two nuclei (the polar nuclei) migrate to a central position. In some species the nuclei fuse to give rise to the secondary endosperm nucleus, in others the polar nuclei just fuse partially prior to fertilization. During cell differentiation the polarity of chalazalmicropyle axis established in the beginning of the female gametophyte development will determine that the nuclei positioned at the micropylar end become specified to develop into an egg and synergids cells and the chalazal nuclei give rise to the antipodal cells. Cell walls are absent in the chalazal end of the egg cell and the synergids, allowing the direct contact of plasma membranes (Willemse and van Went, 1984; Webb and Gunning, 1994b). The polarity of the female gametophyte is believed to be defined by the asymmetry of the surrounding ovule layers and thus to be under sporophytic control, but no factors have yet been identified (Christensen et al., 1997).

Most of the gametophytic mutants, which do not show lesions on the sporophytic tissues of the ovule, fall in different classes corresponding to key developmental events during megagametogenesis, such as mitosis, vacuole formation, nuclear fusion, cellularization and cell death (see categories in Fig. 4) (Feldmann et al., 1997; Schneitz et al., 1997; Christensen et al., 1998; Drews et al., 1998).

\section{Conclusions}

Albeit covering most of the recent info, namely the fast accumulating genomic and transcriptomic data, this review mostly highlights the incompleteness of our understanding of many of the fundamental mechanisms underlying the complex puzzle of gametogenesis. Both gametophytes show developmental programs that prepare these tissues for their future interactions. The events that lead to gametophyte development are controlled primary by the sporophytic tissues, but are ultimately reassigned to singular cells with a narrow set of functions to accomplish. When first released from the sporophyte, the male gametophyte is already committed to a role. The female tissues, on the other hand, form a long and complex pathway, branded by different molecular and cellular contexts. The past years have seen significant advances in our understanding of all these processes, revealing some of the key cellular events, but the identity of many of the molecular components and signaling pathways in which they are involved is still mostly unknown. Moreover, the genetic and functional analysis has mostly progressed on a gene-by-gene basis and relying on the relative serendipity of genetic screens, but transcriptomics offers the promise of major advances through a more deterministic approach. Near future will prove these to be sound basis to a more integrated view of the processes of plant gametogenesis.

\section{Acknowledgements}

JAF lab is supported by FCT grants POCTI/BCI/41725/2001, POCTII BCI/46453/2002, POCTI/BIA-BCM/60046/2004 and POCTI/BIA-BCM/ $61270 / 2004$.

\section{References}

AARTS, M.G., HODGE, R., KALANTIDIS, K., FLORACK, D., WILSON, Z.A., MULLIGAN, B.J., STIEKEMA, W.J., SCOTT, R. and PEREIRA, A. (1997). The Arabidopsis MALE STERILITY 2 protein shares similarity with reductases in elongation/condensation complexes. Plant J 12: 615-23.

AARTS, M.G., KEIJZER, C.J., STIEKEMA, W.J. and PEREIRA, A. (1995). Molecular characterization of the CER1 gene of Arabidopsis involved in epicuticular wax biosynthesis and pollen fertility. Plant Cell 7: 2115-27.

AHLERS, F., LAMBERT, J. and WIERMANN, R. (2003). Acetylation and silylation of piperidine solubilized sporopollenin from pollen of Typha angustifolia L. $Z$ Naturforsch [C] 58: 807-11.

ALBANI, D., ALTOSAAR, I., ARNISON, P.G. and FABIJANSKI, S.F. (1991). A gene showing sequence similarity to pectin esterase is specifically expressed in developing pollen of Brassica napus. Sequences in its $5^{\prime}$ flanking region are conserved in other pollen-specific promoters. Plant Mol Biol 16: 501-13.

ALBANI, D., ROBERT, L.S., DONALDSON, P.A., ALTOSAAR, I., ARNISON, P.G. and FABIJANSKI, S.F. (1990). Characterization of a pollen-specific gene family from Brassica napus which is activated during early microspore development. Plant Mol Biol 15: 605-22.

ANGENENT, G.C., FRANKEN, J., BUSSCHER, M., VAN DIJKEN, A., VAN WENT, J.L., DONS, H.J. and VAN TUNEN, A.J. (1995). A novel class of MADS box genes is involved in ovule development in petunia. Plant Cell 7: 1569-82.

AOUALI, N., LAPORTE, P. and CLEMENT, C. (2001). Pectin secretion and distribution in the anther during pollen development in Lilium. Planta 213: 719.

ARIIZUMI, T., HATAKEYAMA, K., HINATA, K., SATO, S., KATO, T., TABATA, S. and TORIYAMA, K. (2003). A novel male-sterile mutant of Arabidopsis thaliana, faceless pollen-1, produces pollen with a smooth surface and an acetolysissensitive exine. Plant Mol Biol 53: 107-16.

ARONDEL, V.V., VERGNOLLE, C., CANTREL, C. and KADER, J. (2000). Lipid transfer proteins are encoded by a small multigene family in Arabidopsis thaliana. Plant Sci 157: 1-12.

ATANASSOV, I., RUSSINOVA, E., ANTONOV, L. and ATANASSOV, A. (1998). Expression of an anther-specific chalcone synthase-like gene is correlated with uninucleate microspore development in Nicotiana sy/vestris. Plant Mol Bio/ 38 : 1169-78.

BAJON, C., HORLOW, C., MOTAMAYOR, J.C., SAUVANET, A. and ROBERT, D. (1999). Megasporogenesis in Arabidopsis thaliana L.: and ultrastructural study. Sex Plant Reprod 12: 99-109.

BARRETT, S.C. (2002). The evolution of plant sexual diversity. Nat Rev Genet 3: 274-84.

BATE, N., SPURR, C., FOSTER, G.D. and TWELL, D. (1996). Maturation-specific translational enhancement mediated by the 5 '-UTR of a late pollen transcript. Plant J. 10: 613-23.

BAULCOMBE, D. (2004). RNA silencing in plants. Nature 431: 356-363.

BECKER, J.D., BOAVIDA, L.C., CARNEIRO, J., HAURY, M. and FEIJO, J.A. (2003). Transcriptional profiling of Arabidopsis tissues reveals the unique characteristics of the pollen transcriptome. Plant Physiol 133: 713-725.

BEDINGER, P.A. and EDGERTON, M.D. (1990). Developmental staging of maize microspores reveals a transition in developing microspores. Plant Physio/ 92: 474-479.

BIH, F.Y., WU, S.S., RATNAYAKE, C., WALLING, L.L., NOTHNAGEL, E.A. and HUANG, A.H. (1999). The predominant protein on the surface of maize pollen is an endoxylanase synthesized by a tapetum mRNA with a long 5 ' leader. J Biol Chem 274: 22884-94.

BIRD, J., PORTER, E.K. and DICKINSON, H.G. (1983). Events in the cytoplasm during male meiosis in Lilium. J Cell Sci 59: 27-42.

BOAVIDA, L.C., VIEIRA, A.M., BECKER, J.D. and FEIJO, J.A. (2005). Gametophyte interaction and sexual reproduction: how plants make a zygote. Int. J. Dev. Biol. 49: 615-632.

BOWMAN, J.L., BAUM, S.F., ESHED, Y., PUTTERILL, J. and ALVAREZ, J. (1999). Molecular genetics of gynoecium development in Arabidopsis. Curr Top Dev Biol 45: 155-205.

BROOKS, J. and SHAW, G. (1968). Chemical structure of the exine of pollen walls 
and a new function for carotenoids in nature. Nature 219: 532-3.

BROWN, R.C. and LEMMON, B.E. (1991). Pollen developement in orchid. 3. A novel generative pole microtubule system predicts unequal pollen mitosis. $J$ Cell Sci 99: 273-281.

BROWN, S.M. and CROUCH, M.L. (1990). Characterization of a gene family abundantly expressed in Oenothera organensis pollen that shows sequence similarity to polygalacturonase. Plant Cell 2: 263-74.

BUCCIAGLIA, P.A., ZIMMERMANN, E. and SMITH, A.G. (2003). Functional analysis of a beta-1,3-glucanase gene ( Tag1) with anther-specific RNA and protein accumulation using antisense RNA inhibition. JPlant Physio/160: 136773.

BURBULIS, I.E., IACOBUCCI, M. and SHIRLEY, B.W. (1996). A null mutation in the first enzyme of flavonoid biosynthesis does not affect male fertility in Arabidopsis. Plant Cel/ 8: 1013-25.

BYZOVA, M.V., FRANKEN, J., AARTS, M.G., DE ALMEIDA-ENGLER, J., ENGLER, G., MARIANI, C., VAN LOOKEREN CAMPAGNE, M.M. and ANGENENT, G.C. (1999). Arabidopsis STERILE APETALA, a multifunctional gene regulating inflorescence, flower and ovule development. Genes Dev 13: 1002-14.

CAFFREY, M., WERNER, B.G. and PRIESTLEY, D.A. (1987). A crystalline lipid phase in a dry biological system: evidence from $X$-ray diffraction analysis of Typha latifolia pollen. Biochim Biophys Acta 921: 124-34.

CARYL, A.P., JONES, G.H. and FRANKLIN, F.C. (2003). Dissecting plant meiosis using Arabidopsis thaliana mutants. J Exp Bot 54: 25-38.

CHAUDHURY, A.M. and BERGER, F. (2001). Maternal control of seed development. Semin Cell Dev Biol 12: 381-6.

CHAUDHURY, A.M., KOLTUNOW, A., PAYNE, T., LUO, M., TUCKER, M.R., DENNIS, E.S. and PEACOCK, W.J. (2001). Control of early seed development. Annu Rev Cell Dev Biol 17: 677-99.

CHEN, Y.C. and MCCORMICK, S. (1996). Sidecar pollen, an Arabidopsis thaliana male gametophytic mutant with aberrant cell divisions during pollen development. Development 122: 3243-53.

CHEUNG, A.Y. (2001). Imaging elongating pollen tubes by green fluorescent protein. Sex. Plant Reprod. 14: 9-14.

CHEUNG, A.Y., CHEN, C.Y.H., TAO, L.Z. andREYEVA, T., TWELL, D. and WU, H.M. (2003). Regulation of pollen tube growth by Rac-like GTPases. J Exp Bot 54: 73-81.

CHEVALIER, F., MARTIN, O., ROFIDAL, V., DEVAUCHELLE, A.D., BARTEAU, S., SOMMERER, N. and ROSSIGNOL, M. (2004). Proteomic investigation of natural variation between Arabidopsis ecotypes. Proteomics 4: 1372-1381.

CHRISTENSEN, C.A., GORSICH, S.W., BROWN, R.H., JONES, L.G., BROWN, J., SHAW, J.M. and DREWS, G.N. (2002). Mitochondrial GFA2 is required for synergid cell death in Arabidopsis. Plant Cell 14: 2215-2232.

CHRISTENSEN, C.A., KING, E.J., JORDAN, J.R. and DREWS, G.N. (1997). Megagametogenesis in Arabidopsis wild type and the Gf mutant. Sex. Plant Reprod. 10: 49-64.

CNudde, F., MORETTI, C., PORCEDdU, A., PEZZOTTI, M. and GERATS, T. (2003). Transcript profiling on developing Petunia hybrida floral organs. Sex. Plant Reprod. 16: 77-85.

COLOMBO, L., FRANKEN, J., KOETJE, E., VAN WENT, J., DONS, H.J., ANGENENT, G.C. and VAN TUNEN, A.J. (1995). The petunia MADS box gene FBP11 determines ovule identity. Plant Cell 7: 1859-68.

CROSSLEY, S.J., GREENLAND, A.J. and DICKINSON, H.G. (1995). The characterisation of tapetum-specific cDNAs isolated from a Lilium henryi $L$. meiocyte subtractive cDNA library. Planta 196: 523-9.

CUSTERS, J.B., OLDENHOF, M.T., SCHRAUWEN, J.A., CORDEWENER, J.H., WULLEMS, G.J. and VAN LOOKEREN CAMPAGNE, M.M. (1997). Analysis of microspore-specific promoters in transgenic tobacco. Plant Mol Biol 35: 68999.

DA COSTA-NUNES, J.A. and GROSSNIKLAUS, U. (2004). Unveiling the geneexpression profile of pollen. Genome Biology 5: 205.

DARWIN, C. (1862). Fertlization of orchids by insects. Murray, J., London.

DEBOO, G.B., ALBERTSEN, M.C. and TAYLOR, L.P. (1995). Flavanone 3Hydroxylase Transcripts and Flavonol Accumulation Are Temporally Coordinate in Maize Anthers. Plant J. 7: 703-713.

DICKINSON, H.G., ELLEMAN, C.J. and DOUGHTY, J. (2000). Pollen coatings - chimaeric genetics and new functions. Sex Plant Reprod 12: 302-309.

DODDS, P.N., BONIG, I., DU, H., RODIN, J. andERSON, M.A., NEWBIGIN, E. and CLARKE, A.E. (1993). S-RNase gene of Nicotiana alata is expressed in developing pollen. Plant Cell 5: 1771-82.

DOUGHTY, J., HEDDERSON, F., MCCUBBIN, A. and DICKINSON, H. (1993). Interaction between a coating-borne peptide of the Brassica pollen grain and stigmatic S (self-incompatibility)-locus-specific glycoproteins. Proc Nat/ Acad Sci USA 90: 467-71.

DREWS, G.N., LEE, D. and CHRISTENSEN, C.A. (1998). Genetic analysis of female gametophyte development and function. Plant Cel/ 10:5-17.

EADY, C., LINDSEY, K. and TWELL, D. (1995). The significance of microspore division and division symmetry for vegetative cell-specific transcription and generative cell differentiation. Plant Cell 7: 65-74.

ELLIOTT, R.C., BETZNER, A.S., HUTTNER, E., OAKES, M.P., TUCKER, W.Q., GERENTES, D., PEREZ, P. and SMYTH, D.R. (1996). AINTEGUMENTA, an APETALA2 -like gene of Arabidopsis with pleiotropic roles in ovule development and floral organ growth. Plant Cell 8: 155-68.

ENDRESS, P.K. and IGERSHEIM, A. (1999). Gynoecium diversity and systematics of the basal eudicots. Bot J Linn SoC 130: 305-393.

ENGEL, M.L., CHABOUD, A., DUMAS, C. and MCCORMICK, S. (2003). Sperm cells of Zea mays have a complex complement of mRNAs. Plant J. 34:697-707.

EVANS, D.E., TAYLOR, P.E., SINGH, M.B. and KNOX, R.B. (1992). The interrelationship between the accumulation of lipids, protein and the level of acyl carrier protein during the development of Brassica Napus L. Pollen. Planta 186: 343354.

EVANS, P.T. and MALMBERG, R.L. (1989). Alternative pathways of tobacco placental development: time of commitment and analysis of a mutant. Dev Biol 136: 273-83.

EYAL, Y., CURIE, C. and MCCORMICK, S. (1995). Pollen specificity elements reside in $30 \mathrm{bp}$ of the proximal promoters of two pollen-expressed genes. Plant Cell 7: 373-84.

FAURE, J.E., ROTMAN, N., FORTUNE, P. and DUMAS, C. (2002). Fertilization in Arabidopsis thaliana wild type: developmental stages and time course. Plant $J$ 30: 481-8.

FEIJO, J.A., COSTA, S.S., PRADO, A.M., BECKER, J.D. and CERTAL, A.C. (2004). Signalling by tips. Curr Opin Plant Biol 7: 589-598.

FEIJO, J.A., MALHO, R. and OBERMEYER, G. (1995). Ion dynamics and its possible role during in vitro pollen germination and tube growth. Protoplasma 187: $155-167$.

FELDMANN, K.A., COURY, D.A. and CHRISTIANSON, M.L. (1997). Exceptional segregation of a selectable marker (KanR) in Arabidopsis identifies genes important for gametophytic growth and development. Genetics 147: 1411-22.

FERRANDIZ, C., PELAZ, S. and YANOFSKY, M.F. (1999). Control of carpel and fruit development in Arabidopsis. Ann Rev Biochem 68: 321-54.

FIEBIG, A., KIMPORT, R. and PREUSS, D. (2004). Comparisons of pollen coat genes across Brassicaceae species reveal rapid evolution by repeat expansion and diversification. Proc Nat/ Acad Sci USA 101: 3286-91.

FIEBIG, A., MAYFIELD, J.A., MILEY, N.L., CHAU, S., FISCHER, R.L. and PREUSS, D. (2000). Alterations in CER6, a gene identical to CUT1, differentially affect long-chain lipid content on the surface of pollen and stems. Plant Cel/ 12:20018.

FITZGERALD, M.A. and KNOX, R.B. (1995). Initiation of premexine in freezesubstituted microspores of Brassica campestris. Sex. Plant Reprod. 8: 99-104.

FOSTER, G.D., ROBINSON, S.W., BLUNDELL, R.P., ROBERTS, M.R. and HODGE, R. (1992). A Brassica napus mRNA encoding a protein homologous to phospholipid transfer proteins, is expressed especifically in the tapetum and developing microspores. Plant Sci 84: 184-192.

FRANKEL, R., IZHAR, S. and NITSAN, J. (1969). Timing of callase activity and cytoplasmic male sterility in Petunia. Biochem Genet 3: 451-5.

FURNESS, C.A. and RUDALL, P.J. (2001). The tapetum in basal angiosperms: Early diversity. Int J Plant Sci 162: 375-392.

GASSER, C.S., BROADHVEST, J. and HAUSER, B.A. (1998). Genetic analysis of ovule development. Annu Rev Plant Phys 49: 1-24.

GEROLA, P.D., MOL, C.A., NEWBIGIN, E. and LUSH, W.M. (2000). Regulation of $\angle A T 52$ promoter activity during pollen tube growth through the pistil of Nicotiana 
alata. Sex. Plant Reprod. 12: 347-352.

GOLDBERG, R.B., BEALS, T.P. and SANDERS, P.M. (1993). Anther development: basic principles and practical applications. Plant Cel/ 5: 1217-29.

GROSSNIKLAUS, U. and SCHNEITZ, K. (1998). The molecular and genetic basis of ovule and megagametophyte development. Semin Cell Dev Biol 9: 227-38.

GUERRERO, F.D., CROSSLAND, L., SMUTZER, G.S., HAMILTON, D.A. and MASCARENHAS, J.P. (1990). Promoter sequences from a maize pollenspecific gene direct tissue-specific transcription in tobacco. Mol Gen Genet 224: $161-8$.

GUILFORD, W.J., SCHENEIDER, D.M., LABOVITZ, J. and OPELLA, S.J. (1988). High resolution solid state 13C NMR spectroscopy of sporopollenins from different plant taxa. Plant Physiol 86: 851-855.

GUYON, V.N., ASTWOOD, J.D., GARNER, E.C., DUNKER, A.K. and TAYLOR, L.P. (2000). Isolation and characterization of cDNAs expressed in the early stages of flavonol-induced pollen germination in Petunia. Plant Physiol 123: 699-710.

HAMILTON, D.A., ROY, M., RUEDA, J., SINDHU, R.K., SANFORD, J. and MASCARENHAS, J.P. (1992). Dissection of a pollen-specific promoter from maize by transient transformation assays. Plant Mol Biol 18: 211-8.

HAMILTON, D.A., SCHWARZ, Y.H. and MASCARENHAS, J.P. (1998). A monocot pollen-specific promoter contains separable pollen-specific and quantitative elements. Plant Mol Biol 38: 663-9.

HANSON, D.D., HAMILTON, D.A., TRAVIS, J.L., BASHE, D.M. and MASCARENHAS, J.P. (1989). Characterization of a pollen-specific cDNA clone from Zea mays and its expression. Plant Cell 1: 173-9.

HATAKEYAMA, K., ISHIGURO, S., OKADA, K., TAKASAKI, T. and HINATA, K. (2003). Antisense inhibition of a nuclear gene, BrDAD1, in Brassica causes male sterility that is restorable with jasmonic acid treatment. Mol. Breed. 11: 325-336.

HEMSLEY, A.R., GRIFFITHS, P.C., MATHIAS, R. and MOORE, S.E.M. (2003). A model for the role of surfactants in the assembly of exine sculpture. Grana 42 : 38-42.

HENNIG, L., GRUISSEM, W., GROSSNIKLAUS, U. and KOHLER, C. (2004). Transcriptional programs of early reproductive stages in Arabidopsis. Plant Physiol 135: 1765-1775.

HERDT, E., SUTFELD, R. and WIERMANN, R. (1978). The occurrence of enzymes involved in phenylpropanoid metabolism in the tapetum fraction of anthers. Cytobiologie 17: 433-41.

HESLOP-HARRISON, J. (1963). Ultrastructural aspects of differentiation in sporogenous tissue. Symp Soc Exp Biol 17: 315-40.

HESLOP-HARRISON, J. (1966). Cytoplasmic connections between angiosperm meiocytes. Ann. Bot. 30: 221-230.

HESLOP-HARRISON, J. (1968a). Pollen wall development. The succession of events in the growth of intricately patterned pollen walls is described and discussed. Science 161: 230-7.

HESLOP-HARRISON, J. (1968b). Tapetal Origin of Pollen-Coat Substances in Lilium. New Phytologist 67: 779-\&.

HESLOP-HARRISON, J. (1971). Wall pattern formation in angiosperm microsporogenesis. Symp Soc Exp Biol 25: 277-300.

HESLOP-HARRISON, J. (1979). An interpretation of the hydrodynamics of pollen. Am. J. Bot. 66: 737-743.

HIGASHIYAMA, T. (2002). The synergid cell: attractor and acceptor of the pollen tube for double fertilization. J Plant Res 115: 149-60.

HISCOCK, S.J., DEWEY, F.M., COLEMAN, J.O.D. and DICKINSON, H.G. (1994). Identification and localization of an active cutinase in the pollen of Brassica Napus L. Planta 193: 377-384.

HOEKSTRA, F.A. and BRUINSMA, J. (1980). Control of respiration of binucleate and trinucleate pollen under humid conditions. Plant Physiol. 48: 71-77.

HONYS, D. and TWELL, D. (2003). Comparative analysis of the Arabidopsis pollen transcriptome. Plant Physiol. 132: 640-652.

HONYS, D. and TWELL, D. (2004). Transcriptome analysis of haploid male gametophyte development in Arabidopsis. Genome Biology 5:R85.

HORVITZ, H.R. and HERSKOWITZ, I. (1992). Mechanims of asymetric cell division: Two Bs or not to Bs, that is the question. Cell 68: 237-255.
HOWDEN, R., PARK, S.K., MOORE, J.M., ORME, J., GROSSNIKLAUS, U. and TWELL, D. (1998). Selection of T-DNA-tagged male and female gametophytic mutants by segregation distortion in Arabidopsis. Genetics 149: 621-31.

HUANG, B.Q. and RUSSELL, S.D. (1992). Female germ unit: Organization, isolation and function. Int. Rev. Cytol. 140.

HULSKAMP, M., KOPCZAK, S.D., HOREJSI, T.F., KIHL, B.K. and PRUITT, R.E. (1995). Identification of genes required for pollen-stigma recognition in Arabidopsis thaliana. Plant $J$ 8: 703-14.

HULSKAMP, M., PAREKH, N.S., GRINI, P., SCHNEITZ, K., ZIMMERMANN, I., LOLLE, S.J. and PRUITT, R.E. (1997). The STUD gene is required for malespecific cytokinesis after telophase II of meiosis in Arabidopsis thaliana. Dev Biol 187: 114-24.

IRISH, V.F. (1999). Petal and stamen development. Curr Top Dev Bio/ 41: 133-61.

ISHIGURO, S., KAWAI-ODA, A., UEDA, J., NISHIDA, I. and OKADA, K. (2001). The DEFECTIVE IN ANTHER DEHISCIENCE gene encodes a novel phospholipase A1 catalyzing the initial step of jasmonic acid biosynthesis, which synchronizes pollen maturation, anther dehiscence and flower opening in Arabidopsis. Plant Cell 13: 2191-209.

JENIK, P.D. and IRISH, V.F. (2000). Regulation of cell proliferation patterns by homeotic genes during Arabidopsis floral development. Development 127: 1267-76.

JENKS, M.A., TUTTLE, H.A., EIGENBRODE, S.D. and FELDMANN, K.A. (1995). Leaf epicuticular waxes of the Eceriferum mutants in Arabidopsis. Plant Physiol 108: 369-377.

KANG, B.H., RANCOUR, D.M. and BEDNAREK, S.Y. (2003). The dynamin-like protein $A D L 1 C$ is essential for plasma membrane maintenance during pollen maturation. Plant $J$ 35: 1-15.

KAPOOR, S., KOBAYASHI, A. and TAKATSUJI, H. (2002). Silencing of the tapetum-specific zinc finger gene $T A Z 1$ causes premature degeneration of tapetum and pollen abortion in petunia. Plant Cell 14: 2353-67.

KISHITANI, S., YOMODA, A., KONNO, N. and TANAKA, Y. (1993). Involvement of phenylalanine ammonia-lyase in the development of pollen in broccoli (Brassica-Oleracea L.). Sex. Plant Reprod. 6: 244-248.

KLUCHER, K.M., CHOW, H., REISER, L. and FISCHER, R.L. (1996). The AINTEGUMENTA gene of Arabidopsis required for ovule and female gametophyte development is related to the floral homeotic gene APETALA2. Plant Cell 8: 137-53.

KNOX, R.B. and HESLOP-HARRISON, J. (1970). Pollen-wall proteins: localization and enzymic activity. $J$ Cell Sci 6: 1-27.

KOLTUNOW, A.M., TRUETTNER, J., COX, K.H., WALLROTH, M. and GOLDBERG, R.B. (1990). Different temporal and spatial gene expression patterns occur during anther development. Plant Cel/ 2: 1201-1224.

LALANNE, E. and TWELL, D. (2002). Genetic control of male germ unit organization in Arabidopsis. Plant Physiol 129: 865-75.

LAUGA, B., CHARBONNEL-CAMPAA, L. and COMBES, D. (2000). Characterization of $M Z m 3$-3, a Zea mays tapetum-specific transcript. Plant Sci 157: 65-75.

LEE, J.Y. and LEE, D.H. (2003). Use of serial analysis of gene expression technology to reveal changes in gene expression in Arabidopsis pollen undergoing cold stress. Plant Physiol. 132: 517-529.

LI, J., OU-LEE, T.M., RABA, R., AMUNDSON, R.G. and LAST, R.L. (1993). Arabidopsis flavonoid mutants are hypersensitive to UV-B irradiation. Plant Cell 5: 171-179.

LI, Y.Q., FALERI, C., GEITMANN, A., ZHANG, H.Q. and CRESTI, M. (1995). Immunogold localization of arabinogalactan proteins, unesterified and esterified pectins in pollen grains and pollen tubes of Nicotiana-Tabacum-L. Protoplasma 189: 26-36.

LINSKENS, H.F. (1966). Die Änderung des Protein- und Enzym-Musters während der Pollenmeiose und Pollenentwicklung. Planta 69: 79-91.

LIU, J.Q., LEGGEWIE, G., VAROTTO, S. and THOMPSON, R.D. (1999). Characterization of an anther-expressed protein kinase gene in the potato Solanum berthaultii and its antisense inhibition in transgenic plants. Sex Plant Reprod 11: 336-346.

LIU, W.M., MEI, R., DI, X., RYDER, T.B., HUBBELL, E., DEE, S., WEBSTER, T.A., HARRINGTON, C.A., HO, M.H., BAID, J. et al. (2002). Analysis of high density expression microarrays with signed-rank call algorithms. Bioinformatics 18: 
1593-9.

LOMBARDERO, M., BARBAS, J.A., MOSCOSO DEL PRADO, J. and CARREIRA, J. (1994). cDNA sequence analysis of the main olive allergen, Ole e I. Clin Exp Allergy 24: 765-70.

MACKENZIE, A., HESLOP-HARRISON, J. and DICKINSON, H.G. (1967). Elimination of ribosomes during meiotic prophase. Nature 215: 997-9.

MAHESHWARI, P. (1950). McGraw-Hill, New York.

MANDARON, P., NIOGRET, M.F., MACHE, R. and MONÉGER, F. (1990). In vitro protein synthesis in isolated microspores of Zea mays at several stages of development. Theor App/ Genet 80: 134-138.

MARIANI, C., DEBEUCKELEER, M., TRUETTNER, J., LEEMANS, J. and GOLDBERG, R.B. (1990). Induction of male-sterility in plants by a chimeric ribonuclease gene. Nature 347: 737-741.

MASCARENHAS, J.P. (1975). The biochemistry of angiosperm pollen development. Bot Rev 41: 259-314.

MASCARENHAS, J.P. (1989). The male gametophyte of flowering plants. Plant Cel/ 1: 657-664.

MASCARENHAS, J.P. (1990). Gene activity during pollen development. Annu Rev Plant Phys 41: 317-338.

MASCARENHAS, J.P. and BELL, E. (1970). RNA synthesis during development of the male gametophyte of Tradescantia. Dev Biol 21: 475-90.

MASCARENHAS, J.P. and GORALNICK, R.D. (1971). Synthesis of small molecular weight RNA in the pollen tube of Tradescantia paludosa. Biochem. Biophys. Acta. 240: 56-61.

MATSUDA, N., TSUCHIYA, T., KISHITANI, S., TANAKA, Y. and TORIYAMA, K. (1996). Partial male sterility in transgenic tobacco carrying antisense and sense PAL cDNA under the control of a tapetum-specific promoter. Plant Cell Physiol. 37: 215-222.

MAYFIELD, J.A., FIEBIG, A., JOHNSTONE, S.E. and PREUSS, D. (2001). Gene families from the Arabidopsis thaliana pollen coat proteome. Science 292: 2482-5.

MAYFIELD, J.A. and PREUSS, D. (2000). Rapid initiation of Arabidopsis pollination requires the oleosin-domain protein GRP17. Nat Cell Biol 2: 128-30.

MCCORMICK, S. (1993). Male gametophyte development. Plant Cell 5: 12651275.

MCCORMICK, S. (2004). Control of male gametophyte development. Plant Cel/ 16 Suppl: S142-53.

MEYEROWITZ, E.M. (2002). Plants compared to animals: the broadest comparative study of development. Science 295: 1482-5.

MEYERS, B.C., GALBRAITH, D.W., NELSON, T. and AGRAWAL, V. (2004). Methods for transcriptional profiling in plants. Be fruitful and replicate. Plant Physiol 135: 637-652.

MITCHELL, J.W., MANDAVA, N., WORLEY, J.F., PLIMMER, J.R. and SMITH, M.V. (1970). Brassins - a new family of plant hormones from rape pollen. Nature 225: 1065-1066.

MIYAZAKI, S., SUMIKAWA, N., MISHIMA, M., KITANI, M., KUBO, M., DEMURA, T., FUKUDA, H. and HASEBE, M. (2004). Screening of receptor-like kinases of Arabidopsis involved in sexual reproduction mechanism. In Frontiers in Sexual Plant Reproduction I/, pp. 99. Albany, New York, USA.

MOURADOV, A., CREMER, F. and COUPLAND, G. (2002). Control of flowering time: interacting pathways as a basis for diversity. Plant Cel/ 14 Suppl: S11130 .

MURPHY, D.J. and ROSS, J.H. (1998). Biosynthesis, targeting and processing of oleosin-like proteins, which are major pollen coat components in Brassica napus. Plant $J$ 13: 1-16.

MUSCHIETTI, J., DIRCKS, L., VANCANNEYT, G. and MCCORMICK, S. (1994). LAT52 protein is essential for tomato pollen development: pollen expressing antisense $\angle A T 52$ RNA hydrates and germinates abnormally and cannot achieve fertilization. Plant $J$ 6: 321-38.

OLDENHOF, M.T., DEGROOT, P.F.M., VISSER, J.H., SCHRAUWEN, J.A.M. and WULLEMS, G.J. (1996). Isolation and characterization of a microspore-specific gene from tobacco. Plant Mol. Biol. 31: 213-225.

OSTERGAARD, L., PETERSEN, M., MATTSSON, O. and MUNDY, J. (2002). An Arabidopsis callose synthase. Plant Mol. Biol. 49: 559-566.
OTTAVIANO, E., SARI GORLA, M. andnMULCAHY, D.L. (1990). Pollen selection: efficiency and monitoring. Prog Clin Biol Res 344: 575-88.

PACINI, E. (1997). Tapetum character states: analytical keys for tapetum types and activities. Canadian Journal of Botany-Revue Canadienne De Botanique 75: 1448-1459.

PARK, J.H., HALITSCHKE, R., KIM, H.B., BALDWIN, I.T., FELDMANN, K.A. and FEYEREISEN, R. (2002). A knock-out mutation in allene oxide synthase results in male sterility and defective wound signal transduction in Arabidopsis due to a block in jasmonic acid biosynthesis. Plant $J$ 31: 1-12.

PARK, S.K., HOWDEN, R. and TWELL, D. (1998). The Arabidopsis thaliana gametophytic mutation gemini pollen1 disrupts microspore polarity, division asymmetry and pollen cell fate. Development 125: 3789-99.

PAXSON-SOWDERS, D.M., DODRILL, C.H., OWEN, H.A. and MAKAROFF, C.A. (2001). DEX1, a novel plant protein, is required for exine pattern formation during pollen development in Arabidopsis. Plant Physiol 127: 1739-49.

PAXSON-SOWDERS, D.M., OWEN, H.A. and MAKAROFF, C.A. (1997). A comparative ultrastructural analysis of exine pattern development in wild-type Arabidopsis and a mutant defective in pattern formation. Protoplasma 198: 5365.

PEDDADA, L. and MASCARENHAS, J.P. (1975). 5S ribosomal RNA synthesis during pollen development. Dev Growth Diff 17: 1-8.

PIFFANELLI, P., ROSS, J.H. and MURPHY, D.J. (1997). Intra- and extracellular lipid composition and associated gene expression patterns during pollen development in Brassica napus. Plant $J$ 11: 549-62.

PIFFANELLI, P., ROSS, J.H.E. and MURPHY, D.J. (1998). Biogenesis and function of the lipidic structures of pollen grains. Sex Plant Reprod. 11: 65-80.

PINA, C., PINTO, F., FEIJÓ, J.A. and BECKER, J.D. (2005). Gene family analysis of the Arabidopsis pollen transcriptome reveals biological implications for cell growth, division control and gene expression regulation. Plant Physiol 138: 744-756.

PREUSS, D., LEMIEUX, B., YEN, G. and DAVIS, R.W. (1993). A conditional sterile mutation eliminates surface components from Arabidopsis pollen and disrupts cell signaling during fertilization. Genes Dev 7: 974-85.

PREUSS, D., RHEE, S.Y. and DAVIS, R.W. (1994). Tetrad analysis possible in Arabidopsis with mutation of the QUARTET(QRT) genes. Science 264: 145860.

PRUITT, R.E., VIELLE-CALZADA, J.P., PLOENSE, S.E., GROSSNIKLAUS, U. and LOLLE, S.J. (2000). FIDDLEHEAD, a gene required to suppress epidermal cell interactions in Arabidopsis, encodes a putative lipid biosynthetic enzyme. Proc Natl Acad Sci USA 97: 1311-6.

REDMAN, J.C., HAAS, B.J., TANIMOTO, G. and TOWN, C.D. (2004). Development and evaluation of an Arabidopsis whole genome Affymetrix probe array. Plant J 38: 545-561.

REISER, L., MODRUSAN, Z., MARGOSSIAN, L., SAMACH, A., OHAD, N., HAUGHN, G.W. and FISCHER, R.L. (1995). The BELL1 gene encodes a homeodomain protein involved in pattern formation in the Arabidopsis ovule primordium. Cell 83: 735-42.

RHEE, S.Y., OSBORNE, E., POINDEXTER, P.D. and SOMERVILLE, C.R. (2003). Microspore separation in the quartet 3 mutants ofnArabidopsis is impaired by a defect in a developmentally regulated polygalacturonase required for pollen mother cell wall degradation. Plant Physiol 133: 1170-80.

RHEE, S.Y. and SOMERVILLE, C.R. (1998). Tetrad pollen formation in quartet mutants of Arabidopsis thaliana is associated with persistence of pectic polysaccharides of the pollen mother cell wall. Plant $J$ 15: 79-88.

RIEU, I., WOLTERS-ARTS, M., DERKSEN, J., MARIANI, C. and WETERINGS, K. (2003). Ethylene regulates the timing of anther dehiscence in tobacco. Planta 217: 131-7.

ROSS, J.H. and MURPHY, D.J. (1996). Characterization of anther-expressed genes encoding a major class of extracellular oleosin-like proteins in the pollen coat of Brassicaceae. Plant $J$ 9: 625-37.

RUITER, R.K., METTENMEYER, T., VANLAARHOVEN, D., VANELDIK, G.J., DOUGHTY, J., VANHERPEN, M.M.A., SCHRAWWEN, J.A.M., DICKINSON, H.G. and WULLEMS, G.J. (1997a). Proteins of the pollen coat of Brassica oleracea. Plant Physiol 150: 85-91.

RUITER, R.K., VAN ELDIK, G.J., VAN HERPEN, R.M., SCHRAUWEN, J.A. and WULLEMS, G.J. (1997b). Characterization of oleosins in the pollen coat of 
Brassica oleracea. Plant Cell 9: 1621-31.

SCHMID, M., UHLENHAUT, N.H., GODARD, F., DEMAR, M., BRESSAN, R. WEIGEL, D. and LOHMANN, J.U. (2003). Dissection of floral induction pathways using global expression analysis. Development 130: 6001-12.

SCHNEITZ, K., HULSKAMP, M., KOPCZAK, S.D. and PRUITT, R.E. (1997). Dissection of sexual organ ontogenesis: a genetic analysis of ovule development in Arabidopsis thaliana. Development (Cambridge, England) 124: 136776.

SCOTT, R., DAGLESS, E., HODGE, R., PAUL, W., SOUFLERI, I. and DRAPER, J. (1991a). Patterns of gene expression in developing anthers of Brassica napus. Plant Mol Biol 17: 195-207.

SCOTT, R., HODGE, R., PAUL, W. and DRAPER, J. (1991b). The molecular biology of anther differentiation. Plant Sci. 80: 167-191.

SCOTT, R.J. (1994). Pollen exine: the sporopollenin enigma and the physics of pattern. Cambridge University Press, Cambridge, UK.

SCOTT, R.J., SPIELMAN, M. and DICKINSON, H.G. (2004). Stamen structure and function. Plant Cell 16 Suppl: S46-60.

SESSIONS, R.A. (1997). Arabidopsis (Brassicaceae) flower development and gynoecium patterning in wild-type and ettin mutants. Am J Bot 84: 1179-1191.

SESSIONS, R.A. and ZAMBRYSKI, P.C. (1995). Arabidopsis gynoecium structure in the wild and in ettin mutants. Development 121: 1519-32.

SHELDON, J.M. and DICKINSON, H.G. (1983). Determination of patterning in the pollen wall of Lilium henryi. J Cell Sci 63: 191-208.

SHEN, J.B. and HSU, F.C. (1992). Brassica anther-specific genes: characterization and in situ localization of expression. Mol Gen Genet 234: 379-89.

SHERIDAN, W.F., AVALKINA, N.A., SHAMROV, II, BATYGINA, T.B. and GOLUBOVSKAYA, I.N. (1996). The mac1 gene: controlling the commitment to the meiotic pathway in maize. Genetics 142: 1009-20.

SHIMIZU, K.K. and OKADA, K. (2000). Attractive and repulsive interactions between female and male gametophytes in Arabidopsis pollen tube guidance. Development 127: 4511-8.

SIDDIQI, I., GANESH, G., GROSSNIKLAUS, U. and SUBBIAH, V. (2000). The dyad gene is required for progression through female meiosis in Arabidopsis. Development 127: 197-207.

SINGH, M., BLIALLA, P.L., XU, H.L. and SINGH, M.B. (2003). Isolation and characterization of a flowering plant male gametic cell-specific promoter. FEBS Lett. 542: 47-52.

SKINNER, D.J., HILL, T.A. and GASSER, C.S. (2004). Regulation of ovule development. Plant Cell 16 Suppl: S32-45.

SMYTH, D.R., BOWMAN, J.L. and MEYEROWITZ, E.M. (1990). Early flower development in Arabidopsis. Plant Cell 2: 755-67.

SOUTHWORTH, D. and JERNSTEDT, J.A. (1995). Pollen exine development precedes microtubule rearrangement in Vigna-Unguiculata (Fabaceae) - a model for pollen wall patterning. Protoplasma 187: 79-87.

SPIELMAN, M., PREUSS, D., LI, F.L., BROWNE, W.E., SCOTT, R.J. and DICKINSON, H.G. (1997). TETRASPORE is required for male meiotic cytokinesis in Arabidopsis thaliana. Development 124: 2645-57.

STAIGER, D. and APEL, K. (1993). Molecular characterization of two cDNAs from Sinapis alba L. expressed specifically at an early stage of tapetum development. Plant J 4: 697-703.

STEFFENSEN, D.M. (1966). Synthesis of ribosomal RNA during growth and division in Lilium. Exp Cell Res 44: 1-12.

STEINER-LANGE, S., UNTE, U.S., ECKSTEIN, L., YANG, C., WILSON, Z.A., SCHMELZER, E., DEKKER, K. and SAEDLER, H. (2003). Disruption of Arabidopsis thaliana MYB26 results in male sterility due to non-dehiscent anthers. Plant $J$ 34: 519-28.

STINSON, J.R., EISENBERG, A.J., WILLING, R.P., PE, M.E., HANSON, D.D. and MASCARENHAS, J.P. (1987). Genes expressed in the male gametophyte of flowering plants and their isolation. Plant Physiol 83: 442-447.

STINSON, J.R. and MASCARENHAS, J.P. (1985). Onset of alcohol dehydrogenase synthesis during microsporogenesis in maize. Plant Physio/ 77: 222-224.

SUEN, D.F., WU, S.S.H., CHANG, H.C., DHUGGA, K.S. and HUANG, A.H.C. (2003). Cell wall reactive proteins in the coat and wall of maize pollen - Potential role in pollen tube growth on the stigma and through the style. J Bio/ Chem 278:
$43672-43681$

TAYLOR, L.P. and HEPLER, P.K. (1997). Pollen germination and tube growth. Ann Rev Plant Phys Plant Molec Biol 48: 461-491.

TAYLOR, P.E., GLOVER, J.A., LAVITHIS, M., CRAIG, S., SINGH, M.B., KNOX, R.B., DENNIS, E.S. and CHAUDHURY, A.M. (1998). Genetic control of male fertility in Arabidopsis thaliana: structural analyses of postmeiotic developmental mutants. Planta 205: 492-505.

THE ARABIDOPSIS GENOME INITIATIVE. (2000). Analysis of the genome sequence of the flowering plant Arabidopsis thaliana. Nature 408: 796-815.

THEERAKULPISUT, P., XU, H., SINGH, M.B., PETTITT, J.M. and KNOX, R.B. (1991). Isolation and developmental expression of $B c p$ 1, an anther-specific cDNA clone in Brassica campestris. Plant Cel/ 3: 1073-84.

THIMM, O., BLASING, O., GIBON, Y., NAGEL, A., MEYER, S., KRUGER, P., SELBIG, J., MULLER, L.A., RHEE, S.Y. and STITT, M. (2004). MAPMAN: a user-driven tool to display genomics data sets onto diagrams of metabolic pathways and other biological processes. Plant $J$ 37: 914-39.

THOMA, S., HECHT, U., KIPPERS, A., BOTELLA, J., DE VRIES, S. and SOMERVILLE, C. (1994). Tissue-specific expression of a gene encoding a cell wall-localized lipid transfer protein from Arabidopsis. Plant Physiol 105: 35-45.

THOMAS, S.G. and FRANKLIN-TONG, V.E. (2004). Self-incompatibility triggers programmed cell death in Papaver pollen. Nature 429: 305-9.

TWELL, D. (1992). Use of a nuclear-targeted beta-glucuronidase fusion protein to demonstrate vegetative cell-specific gene-expression in developing pollen. Plant J 2: 887-892.

TWELL, D. (2002). The developmental biology of pollen. In Plant Reproduction, vol. 6 (ed. O'NEILL, D. and ROBERTS, J. A.). Sheffield Academic Press Ltd, Sheffield, pp.86-153.

TWELL, D. and HOWDEN, R. (1998). Mechanisms of asymetric division and cell fate determination in developing pollen. INRA-Springer-Verlag, Berlin.

TWELL, D., PARK, S.K. and LALANNE, E. (1998). Asymetric division and cell fate determination in developing pollen. Trends Plant SCi 3: 305-310.

TWELL, D., WING, R., YAMAGUCHI, J. and MCCORMICK, S. (1989). Isolation and expression of an anther-specific gene from tomato. Mol Gen Genet 217: 2405.

TWELL, D., YAMAGUCHI, J., WING, R.A., USHIBA, J. and MCCORMICK, S. (1991). Promoter analysis of genes that are coordinately expressed during pollen development reveals pollen-specific enhancer sequences and shared regulatory elements. Genes Dev 5: 496-507.

URSIN, V.M., YAMAGUCHI, J. and MCCORMICK, S. (1989). Gametophytic and sporophytic expression of anther-specific genes in developing tomato anthers. Plant Cell 1: 727-36.

VAN DER MEER, I.M., STAM, M.E., VAN TUNEN, A.J., MOL, J.N. and STUITJE, A.R. (1992). Antisense inhibition of flavonoid biosynthesis in petunia anthers results in male sterility. Plant Cell 4: 253-62.

VAUGHN, K.C. (1982). Cytochemical demonstration of DNAse in pollen. Histochemistry 73: 487-91.

VITHANAGE, H.I. and KNOX, R.B. (1976). Pollen-wall proteins: quantitative cytochemistry of the origins of intine and exine enzymes in Brassica oleracea. $J$ Cell Sci 21: 423-35.

WANG, A., XIA, Q., XIE, W., DATLA, R. and SELVARAJ, G. (2003). The classical Ubisch bodies carry a sporophytically produced structural protein (RAFTIN) that is essential for pollen development. Proc Nat/ Acad Sci USA 100: 14487-92.

WANG, A., XIA, Q., XIE, W., DUMONCEAUX, T., ZOU, J., DATLA, R. and SELVARAJ, G. (2002). Male gametophyte development in bread wheat (Triticum aestivum L.): molecular, cellular and biochemical analyses of a sporophytic contribution to pollen wall ontogeny. Plant J. 30: 613-23.

WANG, M.-L., HSU, C.-M., CHANG, L.-C., WANG, C.-S., SU, T.-H., HUANG, Y.J.J., JIANG, L. and JAUH, G.-Y. (2004). Gene expression profiles of cold-stored and fresh pollen to investigate pollen germination and growth. Plant Cell Physiol. 45: 1519-1528.

WEBB, M.C. and GUNNING, B.E.S. (1994a). Cell biology of embryo sac development in Arabidopsis. Kluwer Academic Publishers, Dordrecht.

WEBB, M.C. and GUNNING, B.E.S. (1994b). The embryo sac developement in Arabidopsis thaliana. II. The cytoskeleton during megagametogenesis. Sex Plant Reprod 7: 153-163. 


\section{L. Boavida et al.}

WEEDEN, N.F. and GOTTLIEB, L.D. (1979). Distinguishing allozymes and isozymes of phosphoglucoisomerases by electrophoretic comparisons of pollen and somatic tissues. Biochem Genet 17: 287-96.

WETERINGS, K., REIJNEN, W., VAN AARSSEN, R., KORTSTEE, A., SPIJKERS, J., VAN HERPEN, M., SCHRAUWEN, J. and WULLEMS, G. (1992). Characterization of a pollen-specific cDNA clone from Nicotiana tabacum expressed during microgametogenesis and germination. Plant Mol Biol 18: 1101-11.

WETERINGS, K., SCHRAUWEN, J., WULLEMS, G. and TWELL, D. (1995). Functional dissection of the promoter of the pollen-specific gene NTP303 reveals a novel pollen-specific and conserved cis-regulatory element. Plant J. 8: 55-63.

WILLEMSE, M.T. and VAN WENT, J.L. (1984). The female gametophyte. SpringerVerlag, Berlin.

WOLTERS-ARTS, M., LUSH, W.M. and MARIANI, C. (1998). Lipids are required for directional pollen-tube growth. Nature 392: 818-21.

WORRALL, D., HIRD, D.L., HODGE, R., PAUL, W., DRAPER, J. and SCOTT, R. (1992). Premature dissolution of the microsporocyte callose wall causes male sterility in transgenic tobacco. Plant Cell 4: 759-771.

YADEGARI, R. and DREWS, G.N. (2004). Female gametophyte development. Plant Cell 16 Suppl: S133-41.

XU, H., SWOBODA, I., BHALLA, P.L. and SINGH, M.B. (1999). Male gametic cellspecific gene expression in flowering plants. Proc Nat/Acad Sci USA 96: 25548.

YAMAMOTO, Y., NISHIMURA, M., HARA-NISHIMURA, I. and NOGUCHI, T. (2003). Behavior of vacuoles during microspore and pollen development in Arabidopsis thaliana. Plant Cell Physiol 44: 1192-1201.

YANG, C.Y., SPIELMAN, M., COLES, J.P., LI, Y., GHELANI, S., BOURDON, V.,
BROWN, R.C., LEMMON, B.E., SCOTT, R.J. and DICKINSON, H.G. (2003). TETRASPORE encodes a kinesin required for male meiotic cytokinesis in Arabidopsis. Plant J 34: 229-40.

YANG, S.C., SWEETMAN, J.P., AMIRSADEGHI, S., BARGHCHI, M., HUTTLY, A.K., CHUNG, W.I. and TWELL, D. (2001). Novel anther-specific myb genes from tobacco as putative regulators of phenylalanine ammonia-lyase expression. Plant Physiol 126: 1738-1753.

YANG, W.C., YE, D., XU, J. and SUNDARESAN, V. (1999). The SPOROCYTELESS gene of Arabidopsis is required for initiation of sporogenesis and encodes a novel nuclear protein. Genes Devel 13: 2108-17.

YLSTRA, B., MUSKENS, M. and VAN TUNEN, A.J. (1996). Flavonols are not essential for fertilization in Arabidopsis thaliana. Plant Mol Biol 32: 1155-8.

YLSTRA, B., TOURAEV, A., MORENO, R.M.B., STOGER, E., VANTUNEN, A.J., VICENTE, O., MOL, J.N.M. and HEBERLEBORS, E. (1992). Flavonols stimulate development, germination and tube growth of tobacco pollen. Plant Physiol 100: 902-907.

ZHAO, D. and MA, H. (2000). Male fertility: a case of enzyme identity. Curr Biol 10: R904-7.

ZINKL, G.M. and PREUSS, D. (2000). Dissecting Arabidopsis pollen-stigma interactions reveals novel mechanisms that confer mating specificity. Ann Bot 85: 15-21.

ZINKL, G.M., ZWIEBEL, B.I., GRIER, D.G. and PREUSS, D. (1999). Pollen-stigma adhesion in Arabidopsis : a species-specific interaction mediated by lipophilic molecules in the pollen exine. Development 126: 5431-40.

ZONIA, L., TUPY, J. and STAIGER, C.J. (1999). Unique actin and microtubule arrays co-ordinate the differentiation of microspores to mature pollen in Nicotiana tabacum. J Exp Bot 50: 581-594. 